\title{
Regulation of ion channels by muscarinic receptors
}

\author{
David A. Brown
}

Department of Neuroscience, Physiology \& Pharmacology, University College London, London, WC1E 6BT (UK).

Contact address:

Professor D.A.Brown, FRS,

Department of Neuroscience, Physiology \& Pharmacology,

University College London, Gower Street,

Londin, WC1E 6BT.

E-mail: d.a.brown@ucl.ac.uk

Telephone: (+44) (0)20 76797297

Mobile (for urgent messages): $(+44)(0) 7766-236330$

\section{Abstract}

The excitable behaviour of neurons is determined by the activity of their endogenous membrane ion channels. Since muscarinic receptors are not themselves ion channels, the acute effects of muscarinic receptor stimulation on neuronal function are governed by the effects of the receptors on these endogenous neuronal ion channels. This review considers some principles and factors determining the interaction between subtypes and classes of muscarinic receptors with neuronal ion channels, and summarizes the effects of muscarinic receptor stimulation on a number of different channels, the mechanisms of receptor - channel transduction and their direct consequences for neuronal activity. Ion channels considered include potassium channels (voltage-gated, inward rectifier and calcium activated), voltage-gated calcium channels, cation channels and chloride channels.

Key words: Ion channels; neuronal excitation and inhibition; pre- and postsynaptic events; muscarinic receptor subtypes; $\mathrm{G}$ proteins; transduction mechanisms.

Contents.

1. Introduction: some principles of muscarinic receptor - ion channel coupling.

1.2 Some consequences of the indirect link between receptor and ion channel. The connection between $M_{1} R s$ and the $M$-type $K^{+}$channel as a model system

1.2.1 Dynamics of the response

1.2.2 Sensitivity of the response to agonist stimulation

2. Some muscarinic receptor-modulated neural ion channels. 
$2.1 \mathrm{G}_{\mathrm{q}}$-coupled muscarinic receptors.

2.1.1. $\mathrm{K}^{+}$-channel inhibition.

2.1.1.1. Inhibition of potassium "leak" channels.

2.1.1.2 Inhibition of M-type $K_{v} 7$ potassium channels ("M-channels", $\left.I_{k(M)}\right)$.

2.1.1.3. Inhibition of EAG and related voltage-gated $\left(K_{v} 10\right)$ potassium channels.

2.1.1.4. Inhibition of $\mathrm{K}_{\mathrm{ir}}$ inward rectifier $\mathrm{K}^{+}$channels.

2.1.1.5. Inhibition of calcium-activated potassium currents ( $\mathrm{K}_{\mathrm{ca}}$ currents).

2.1.1.6. Summary statement on $\mathrm{K}^{+}$channel inhibition

2.1.2. Inhibition and activation of chloride channels.

2.1.3. Activation of cation channels.

2.1.4. Inhibition of voltage-gated calcium currents.

3. Ion channel responses to $\mathrm{G}_{\mathrm{i}} / \mathrm{G}_{\mathrm{o}}$-coupled $\mathrm{M}_{2} / \mathrm{M}_{4}$ receptors.

3.1.Activation of $\mathrm{K}_{\mathrm{ir}}$ potassium channels.

3.1.1. Other muscarinic hyperpolarizations

3.2. Inhibition of Cav2 voltage-gated calcium channels.

3.2.1. Some particulars of muscarinic inhibition.

3.2.2 Physiological consequences of muscarinic inhibition of Cav2 channels.

3.2.3. Inward rectifier $\mathrm{K}^{+}$channels and transmitter release.

4. Final thoughts.

\section{Abbreviations}

AHP, $I_{\text {AHP }} \quad$ After-hyperpolarization; calcium-dependent afterhyperpolarizing current

AKAP A-kinase anchoring protein

DAG diacylglycerol

EAG Ether-a-gogo (Kv10) potassium channels

Erg EAG-related (Kv11) potassium channels

IP3 inositol-1,4,5-trisphosphate

IP3R inositol-1,4,5-trisphosphate receptor

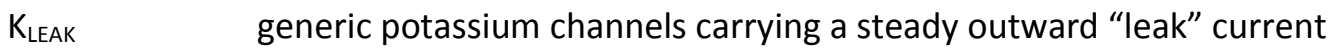

$\mathrm{K}_{\mathrm{M}} \quad \mathrm{M}$-type potassium channel (usually formed by $\mathrm{K}_{\mathrm{v}} 7.2 / 7.3$ heteromers) 


$\begin{array}{ll}\mathrm{M}_{1} \mathrm{R}, \mathrm{M}_{2} \mathrm{R} \text { etc } & \mathrm{M}_{1} \text { muscarinic receptor, } \mathrm{M}_{2} \text { muscarinic receptor, etc } \\ \mathrm{PI} & \text { phosphatidylinositol } \\ \text { PI-4K } & \text { phosphatidylinositol-4-kinase } \\ \text { PI4P-5K } & \text { phosphatidylinositol-4-phosphate-5-kinase } \\ \text { PIP } & \text { phosphatidylinositol-4-phosphate } \\ \text { PIP2 } & \text { phosphatidylinositol-4,5-bisphosphate } \\ \text { PKC } & \text { protein kinase C } \\ \text { PLC } & \text { phospholipase C }\end{array}$

\section{Introduction: some principles of muscarinic receptor - ion channel coupling.}

In the short term at least, information transfer in the nervous system is effected by electrical impulses generated by the opening and closing of plasma membrane ion channels. Unlike nicotinic acetylcholine receptors, muscarinic receptors do not themselves constitute ion channels; nor do they act as a ligand-sensitive channel subunit. Hence, in order to modify information transfer, the activation of muscarinic receptors has to be transduced into a change in the activity of one or more endogenous ion channels that regulate neural excitability. While it appears possible to generate an artificial directly-coupled muscarinic receptor - ion channel concatemer (Moreau et al., 2008), coupling between native receptors and ion channels is more indirect.

With some possible exceptions (e.g., Rolland et al., 2002; Sun et al., 2007), transduction from receptor to ion channel is mediated by the receptor's cognate $\mathrm{G}$ protein and/or other effectors consequential on $\mathrm{G}$ protein activation. This means that, from the ion channel's viewpoint, the receptor is merely the trigger for generating the requisite transducing molecule(s). Hence, in an "open system" containing all 5 muscarinic receptors in equal density, with all of the cognate $G$ proteins and $G$ protein-responsive enzyme systems available, a channel that is regulated by a downstream product of (say) $G_{q}$ activation has no way of distinguishing whether $G_{q}$ has been activated by $M_{1}, M_{3}$ or $M_{5}$ receptors; likewise a channel response to $G_{i}$ or $G_{0} G$ proteins, or subunits thereof, is independent of whether the $G$ protein is activated by $\mathrm{M}_{2}$ or $\mathrm{M}_{4}$ receptors. This is pretty much the situation when responses to heterologously-expressed receptors are compared in clonal cell lines (see Table 2 in Hulme et al., 1990; see also Higashida et al., 1990; Robbins et al, 1990).

However more subtype selectivity frequently occurs in physiological systems as a result of anatomical differences in subtype distribution, or from micro-anatomical constraints on receptor subtype - ion channel coupling, or from other causes. To give an example of subtype-selective ion channel modulation in nerve cells not predicted from experiments on 
reconstituted systems. In the latter, inward rectifier $\mathrm{K}_{\mathrm{ir}} 3$ potassium channels and Cav2 ("Ntype") calcium channels are modulated equally well by $\mathrm{M}_{2}$ and $\mathrm{M}_{4}$ receptors (Hulme et al., 1990; Higashida et al., 1990). However, in cells of the rat sympathetic ganglion, which possess both $\mathrm{M}_{2}$ and $\mathrm{M}_{4}$ receptor subtypes, the Cav2 $\mathrm{Ca}^{2+}$ channel is selectively inhibited by activating $M_{4}$ receptors (Bernheim et al., 1992) but not by stimulating $M_{2}$ receptors (Fernandez et al., 1999); instead the endogenous $M_{2}$ receptors can activate expressed $\mathrm{K}_{\mathrm{ir}} 3$ channels, whereas the $M_{4}$ receptors cannot (Fernandez et al, 1999). In both cases the channels are modulated by the $\beta \gamma$ subunits of the $G$ proteins $G_{i}$ and $G_{0}$, and in reconstituted systems the upstream source of these $\beta \gamma$ subunits cannot be distinguished ${ }^{1}$. The precise cause of this remarkably sharp physiological discrimination has not yet been established. Most probably it lies in a micro-anatomical segregation of the receptor and its cognate channel into a "signalosome" or "microdomain", perhaps facilitated by ancillary proteins such as RGS proteins (Abramow-Newerly et al., 2006) or other associated proteins (BorrotoEscuela et al., 2011) and in which the relevant signalling proteins may be partially precoupled (Nobles et al., 2005). Further, there may also be species differences in the way individual M-receptor subtypes are coupled to ion channels. Thus, in cells from mouse sympathetic neurons, Cav2 inhibition is driven by $M_{2}$ receptors, not by $M_{4}$, as judged from genetic knock-outs (Shapiro et al., 1999). Hence, although the particular subtype regulating an individual ion channel may well be crucially important from a pharmacological or therapeutic standpoint, this cannot be deduced from the channel response itself.

\subsection{Some consequences of the indirect link between receptor and ion channel.}

The connection between $M_{1} R$ s and the $M$-type $K^{+}$channel as a model system

The indirect multi-step pathway between muscarinic receptor activation and ion channel response has important consequences for both the kinetics and agonist sensitivity of the response. This has been analysed most thoroughly for the pathway connecting the activation of the $\mathrm{M}_{1}$ receptor to the inhibition of the voltage-gated " $\mathrm{M}$-channel" ( $\mathrm{K}_{\mathrm{M}}$; Brown \& Adams, 1980), principally by B. Hille and his colleagues (summarized in Hille et al., 2014). The M-channels themselves are composed of $\mathrm{K}_{\mathrm{v}} 7.2$ and 7.3 subunits (KCNQ2 and KCNQ3 gene products) (Wang et al., 1998) and require the membrane phospholipid phosphatidylinositol-4,5-bisphosphate (PIP2) to enter and maintain the open state (Suh \& Hille, 2002; Zhang et al., 2003; Gamper \& Shapiro, 2007; Telezhkin et al., 2012). $M_{1} R$ activation closes the channels by activating $G_{q}$, thence stimulating phospholipase $C \beta$ (PLC $\beta$ ) to hydrolyse PIP2 and reduce membrane PIP2 to levels below those needed to keep the channels open (Winks et al., 2005; Delmas \& Brown, 2005). The PIP2 hydrolysis products inositol-4,5-trisphosphate (IP3) and diacylglycerol (DAG) do not contribute directly to muscarinic $\mathrm{K}_{\mathrm{M}}$ inhibition, at least in neurons (see Clapp et al, 1992 for smooth muscle), though DAG can assist closure by activating protein kinase $C$ (PKC) to phosphorylate the

\footnotetext{
${ }^{1}$ Thus, when $\mathrm{K}_{\mathrm{i}} 3$ activation by $\mathrm{M}_{2} \mathrm{Rs}$ was prevented with Pertussis toxin(PTX), inhibition could be resurrected by exogenous expression of PTX-insensitive versions of either $G_{\alpha 0}$ or $G_{\alpha l}$ proteins with $\beta_{1} \gamma_{2}$ subunits (Fernandez et al., 2001). Hence $M_{2} R s$ were not incapable of activating $\mathrm{K}_{\mathrm{ir}} 3$ in sympathetic neurons, but failed to do via the complement of $\mathrm{G}$ protein subunits available to them in their natural environment. It should also be noted that neither the Cav2 channels in these neurons (Jeong \& Ikeda, 1999; Ruiz-Velasco \& Ikeda, 2000) nor the Kir3 channels in other cells (Wickman \& Clapham, 1995) show any strong selectivity in their response to different $\beta \gamma$-subunit combinations. Hence it seems unlikely that receptor $\mathrm{K}_{\mathrm{ir}} / \mathrm{Cav2}$ selectivity depends on difference in $\beta \gamma$ contributions (cf. Kleuss et al., 1993).
} 
channels and reduce their apparent affinity for PIP2 (Hoshi et al., 2003; Kosenko et al., 2012).

The pathway may be depicted in very simplified form as follows:

$\mathrm{A}+\mathrm{R} \rightarrow \mathrm{AR} \rightarrow \mathrm{AR}^{*}+\mathrm{G}_{\alpha q-\mathrm{GDP}} \beta \gamma \rightarrow \mathrm{G}_{\alpha q-\mathrm{GTP}} \rightarrow \mathrm{PLC} \beta \rightarrow \mathrm{PIP} 2-\mathrm{K}_{\mathrm{M} \text { (open) }} \rightarrow \mathrm{K}_{\mathrm{M} \text { (closed) }}+\mathrm{DAG}+\mathrm{IP} 3 \rightarrow \mathrm{Ca}$
(1)
(2) (3) (4)
(5)
(6)
(7)
(8)
(9a) (9b) (10)

where $\mathrm{A}=$ agonist and $\mathrm{R}=$ receptor .

1.2.1 Dynamics of the response. In sympathetic neurons, the channels close within about 10 s after applying a receptor-saturating concentration of agonist and recover with a timeconstant of 42s following agonist washout (Kruse et al., 2016) (Fig.1). Most of the onset time-course is taken up by steps $5 \rightarrow 6$ and $6 \rightarrow 7$, and can be accelerated by over-expressing PLC(Jensen et al., 2009). Channel closure is closely time-locked to the hydrolysis of PIP2 (Fig.1A) and the loss of PIP2 from the membrane (Fig.1B). Recovery requires the resynthesis of PIP2 from phosphatidylinositol (PI) and phosphatidylinositol-4-phosphate (PIP) by the enzymes $\mathrm{PI}-4$ kinase (PI-4K) and PI4P-5kinase (PI4P-5K) respectively, the former being ratelimiting.

\section{Fig.1 near here.}

The latency to detectable channel closure following a fast agonist concentration jump (delivered via a pulse of synaptically-released acetylcholine) is around $2 \mathrm{~s}$ at $24^{\circ} \mathrm{C}$ (Fig.2A, upper record). About half of this reflects the time taken from agonist binding to receptors to activation of PLC (Falkenburger et al., 2010a); channel closure follows within tens of milliseconds when PIP2 is dephosphorylated (Falkenburger et al, 2010b) or hydrolyzed. The latency shortens dramatically to around $250 \mathrm{~ms}$ on raising the temperature to $34^{\circ} \mathrm{C}$ (Fig.2A, middle record). It is interesting to compare these latencies with the latency to activation of the cardiac inward rectifier current by $M_{2} R s$; this does not require an enzymatic step but is driven directly by $\beta \gamma$ subunits released from the activated $\mathrm{G}_{i} \alpha \beta \gamma$-trimer (Wickman \& Clapham, 1995):

$$
\mathrm{A}+\mathrm{R} \rightarrow \mathrm{AR} \rightarrow \mathrm{AR}^{*}+\mathrm{G}_{\alpha i \beta \gamma} \rightarrow \mathrm{G}_{\alpha \mathrm{i}-\mathrm{GTP}}+\mathrm{G}_{\beta \gamma} \rightarrow \mathrm{K}_{\mathrm{ir}}
$$

In this case (Fig 2B) the latency (about $50 \mathrm{~ms}$ ) was clearly shorter than the $250 \mathrm{~ms}$ required for M-current inhibition at a comparable temperature; and the current rise time-constant is around $300 \mathrm{~ms}$ instead of $3 \mathrm{~s}$. Apart from the omission of the enzymatic step, two further factors can accelerate $K_{\text {ir }}$ activation. (1). Kinetics are likely to be accelerated by associated RGS proteins such as RGS4 which accelerates current offset by acting as a GTPase-activating protein (GAP) (Doupnik et al., 1997; Saitoh et al., 1997), or RGS8, which accelerates current onset (Jeong \& Ikeda, 2001) (2) The RGS proteins may also act as structural proteins enabling a degree of precoupling between receptor and $\mathrm{G}$ protein and/or $\mathrm{G}$ protein and channel (Fujita et al., 2000, Zhang et al., 2001; Benions et al, 2005, Nobles et al., 2005; AbramowNewerly et al., 2006;Doupnik, 2008), so reducing diffusion times for collision-coupling. [It is worth noting that RGS proteins can also modify the apparent efficacy of partial agonists at $M_{2} R s$ as measured by $K_{\text {ir }}$ current responses (Chen et al., 2014.] 


\section{Fig. 2 near here}

1.2.2 Sensitivity of the response to agonist stimulation. The nature of the pathway between receptor stimulation and ion channel response also has a major influence on the agonist sensitivity of the response. Fig.3, adapted from Hille et al (2014), shows the concentration dependence for some of the subsequent downstream responses following $M_{1} R$ activation, expressed as multiples of the agonist $K_{D}$. These dose-response curves are based on direct experimental measurements of the intermediate events in Tsa-201 fibroblast cells transfected with $M_{1} R s$, coupled with quantitative modelling for an $M_{1}$ receptor density of $500 / \mu \mathrm{m}^{2}$. A notable feature is the progressively increasing sensitivity to an $M_{1}$ agonist the further downstream the target - i.e., the greater the amplification, the more "spare receptors" there are for the muscarinic response. To put this into a physiological context, if $\mathrm{K}_{\mathrm{M}}$ potassium channel closure resulted solely from loss of PIP2, half of the $\mathrm{K}_{\mathrm{M}}$ potassium channels would be closed when about $10 \%$ of the receptors are occupied. However, if some other event (e.g., exocrine secretion or smooth muscle contraction) was being measured that resulted from the release of calcium by the IP3 formed as a result of PIP2 hydrolysis, then a substantial response might be expected when less than $1 \%$ of the receptors were occupied. Thus, in some neuronal cell lines such as NG108-15 neuroblastoma-glioma hybrid cells, activation of $\mathrm{G}_{\mathrm{q}}$-coupled muscarinic receptors produces a large rise in intracellular calcium, sufficient to activate a $\mathrm{Ca}^{2+}$-dependent $\mathrm{K}^{+}$-current (Fukuda et al., 1988; Neher et al., 1988). This response is very rapid: the outward $\mathrm{K}_{\mathrm{Ca}}$ current precedes the subsequent inward current (due to inhibition of the $\mathrm{M}$-like $\mathrm{K}^{+}$current also present in these cells), according with a greater sensitivity of this downstream response to receptor activation. In accord with this, further experiments on NG108-15 cells (Robbins et al., 1993) indicated that at least 10 times less acetylcholine was necessary to release calcium and activate the $\mathrm{K}_{\mathrm{Ca}}$ current than to inhibit the $K_{M}$ current. However, with rare exceptions (see section 3.1.1), primary neurons do not display this form of downstream signalling in response to Gq-coupled muscarinic receptor stimulation, because of insufficient release of intracellular calcium by the receptor (Delmas et al., 2002); this has been ascribed to strong intracellular calcium buffering (Wanaverbecq et al., 2003) plus partial protection of the efficient coupling of the IP3R against IP3 by an IRBIT³-like IP3-binding protein (Zaika et al., 2011; Kruse et al., 2016). Notwithstanding, some other neurons show sufficient $\mathrm{Ca}^{2+}$ release to open $\mathrm{Ca}^{2+}$-sensitive $\mathrm{K}^{+}$ channels (see section 3.1.1 below).

There appears to be no such constraint against the generation of diacylglycerol (DAG) and consequent activation of protein kinase $\mathrm{C}$ (PKC), and several examples of ion channel responses to this downstream consequence of muscarinic receptor-induced PIP2 hydrolysis are documented in section 2 below (e.g., 2.1.1.1, 2.1.1.2(4), 2.1.1.4, 2.1.2.6)

\footnotetext{
2 "Real" cells such as sympathetic neurons have a lower density of $M_{1}$ Rs (probably 30-fold less: Kruse et al., 2016) but the principle of downstream amplification remains the same.

${ }^{3} \mathrm{IRBIT}=\mathrm{IP}_{3} \mathrm{R}$-binding protein released with inositol 1,4,5-trisphosphate
} 
Fig 3 near here.

I should emphasize that this review is restricted to short-term effects on ion channel function. For simplicity's sake, it does not consider distant downstream effects of muscarinic receptor stimulation on ion channels such as those mediated by various kinases activated in consequence of $\mathrm{G}$ protein activation, nor long-term receptor-induced effects on ion channel transcription.

\section{Some muscarinic receptor-modulated neural ion channels.}

As pointed out in section 1, the channel responds to the message generated by the receptor not to the receptor itself, so in principle cannot distinguish between different receptors that generate the same message. Hence, I shall group the channels into those responding to $G_{q}$ coupled receptors $\left(M_{1}, M_{3}, M_{5}\right)$ and $G_{i} / G_{0}$-coupled receptors $\left(M_{2}, M_{4}\right)$, while noting any more specific receptor coupling if known.

\section{$2.1 \mathrm{G}_{\mathrm{q}}$-coupled muscarinic receptors.}

The physiological effects of activating these receptors at the individual neuron level is usually excitatory (though could well be inhibitory to the integrated neuraxis). This commonly arises through: (1) inhibition of potassium channels; (2) inhibition of chloride channels; or (3) activation of cation channels. Inhibition may occur through activation of Cadependent K-channels.

\subsection{1. $\mathrm{K}^{+}$-channel inhibition.}

Why should this be excitatory? If $\mathrm{K}^{+}$channels were the only ion channels in the cell membrane, the membrane potential would be at the $\mathrm{K}^{+}$equilibrium potential as set by the Nernst equation $V_{m}=E_{K}=R T / F \ln \left(\left[K^{+}\right]_{\text {out }} /\left[K^{+}\right]_{\text {in }}\right)^{4}$ and closing the channel would not lead to any current flow or have any effect on the membrane potential (though it would increase the membrane resistance). In practice $V_{m}$ is normally positive to $E_{k}$ because there are other channels in the cell membrane carrying a steady inward (depolarizing) current due to their permeability to ions with a more positive equilibrium potential such as $\mathrm{Na}^{+}, \mathrm{Ca}^{2+}$ or (sometimes) $\mathrm{Cl}^{-}$. When the $\mathrm{K}^{+}$channels are closed, this inward current causes a further depolarization. This increases excitability by bringing the membrane potential nearer to the threshold for action potential generation (and may sometimes itself suffice to induce an action potential discharge); this may be assisted by the increased membrane resistance which allows other excitatory currents such as synaptic potentials to produce larger voltage changes.

\footnotetext{
${ }^{4} \mathrm{~V}_{\mathrm{m}}=$ membrane potential; $\mathrm{V}_{\mathrm{K}}=$ potassium equilibrium potential; $[\mathrm{K}]_{\text {out }}=$ extracellularl $\mathrm{K}^{+}$ion concentration; $[\mathrm{K}]_{\text {in }}=$ intracellular $\mathrm{K}^{+}$ion concentration; $\mathrm{R}=$ gas constant $=8.3 \times 10^{7} \mathrm{ergs} /{ }^{\circ} \mathrm{K} / \mathrm{mole} ; \mathrm{K}=\mathrm{F}=$ Faraday (electrical charge) $=96,500$ coulombs $/$ mole; $K=$ temperature, degrees Kelvin; $R T / F=25 \mathrm{mV}$ at $25^{\circ} \mathrm{C}$.
} 
2.1.1.1. Inhibition of potassium "leak" channels. A $\mathrm{K}^{+}$"leak" current may be defined as one carried by $\mathrm{K}^{+}$channels the open probability of which does not vary with membrane potential (i.e., they are voltage-independent). Although the current-voltage curve may show outward rectification (i.e, channels carry outward current more easily than inward current), this is due to the asymmetric $\mathrm{K}^{+}$concentrations inside and outside the cell as expressed by the Goldman-Hodgkin-Katz equation (see Hodgkin \& Katz, 1949). Leak currents of this type that were inhibited by stimulating $M_{1} R s$ were described some time back in myenteric neurons by Galligan et al (1989) and in hippocampal pyramidal neurons by Madison et al (1987) and Benson et al (1988). The effects of leak channel inhibition are to depolarize the cell and either induce action potential firing or favour increased repetitive firing capacity (see, e.g., Fig.4 below).

One source of MR-sensitive leak currents are members of the $K_{2 \mathrm{P}}(\mathrm{KCNK})$ family of twin-pore potassium channels (Enyedi \& Czirják, 2009; Mathie, 2007; Fig.4)), most notably TASK1 and $3\left(\mathrm{~K}_{2 \mathrm{P}} 3.1,9.1 ; K C N K 3,9\right)$ and TREK1 and 2( $\left.\mathrm{K}_{2 \mathrm{P}} 2.1,10.1 ; K C N K 2,10\right)$. Like $\mathrm{K}_{\mathrm{v}} 7$ (KCNQ) TREK channels are activated by PIP2 and close when PIP2 is hydrolysed or sequestered (Lopes et al., 2005; Lindner et al., 2011). Closure of TREK channels by $M_{1} R s$ is most likely the result of $\mathrm{G}_{\mathrm{q}} / \mathrm{PLC}$-induced PIP2 hydrolysis and associated depletion, since closure was prevented by loading the cell with PIP2 (Bista et al., 2015; Rivas-Ramírez et al., 2015). The mechanism for $M_{3} R$-induced TASK channel closure is more uncertain (Mathie, 2007) since they appear resistant to PIP2 depletion (Lindner et al, 2011). One hypothesis is that closure results from a direct interaction of $G_{\alpha q G T P}$ with the channel (Chen et al., 2006). More recent work suggests that diacyglycerol (DAG), a product of PIP2 hydrolysis, is responsible (Wilke et al., 2014; Biste et al., 2015), though the effects of DAG on TASK channel activity may be complex (Veale et al., 2007).

\section{Fig 4 near here}

2.1.1.2 Inhibition of M-type $K_{\mathrm{v}} 7$ channels ("M-channels", $\left.I_{K(M)}\right)$. The principal transduction mechanism for M-channel closure (hydrolysis and depletion of PIP2) has been discussed in 1.2 above. Some physiological functions and pharmacological properties of the channels are reviewed in Brown \& Passmore (2009). For the present purposes some aspects worth noting are as follows:

(1). Although heteromeric $K_{v} 7 \cdot 2 / 7.3$ subunit combinations appear to form the most usual $M$ channel in the mammalian nervous system, comparable "M-type" currents can be generated by $\mathrm{K}_{\mathrm{v}} 7.2,7.3,7.4$ and 7.5 subunits, assembled either homomerically or in certain heteromeric combinations. Kv7.4-based M-currents are present in cochlear hair cells and other components of the auditory \& vestibular system (Jentsch, 2000), in elements of the mesencephalic dopaminergic system (Hansen et al., 2008), and in some peripheral cutaneous mechanoreceptors (Heidenreich et al, 2011). $\mathrm{K}_{\mathrm{v}}$ 7.5-based M-currents have been identified In large presynaptic terminals within the central auditory system (Huang \& Trussell, 2011) and in certain hippocampal interneurons (Fidzinski et al, 2015). $\mathrm{K}_{\mathrm{v}} 7.4$ and $\mathrm{K}_{\mathrm{v}} 7.5$ (including $\mathrm{K}_{\mathrm{v}} 7.4 / 7.5$ heteromers) also contribute prominently to an M-current that 
regulates membrane potential and contractility in some peripheral smooth muscles, especially vascular smooth muscle (Greenwood \& Ohya, 2009).

Subunit composition is relevant to muscarinic regulation because the subunits vary in their sensitivities to PIP2 and PIP2 depletion (Gamper \& Shapiro, 2007). Thus, Kv 7.3 subunits have about 100-fold greater apparent "affinity" for PIP2 that the other subunits, so M-channels that contain $\mathrm{K}_{\mathrm{v}} 7.3$ subunits will be appreciably more resistant to closure by PIP2 depletion (i.e, will need a higher level of muscarinic receptor occupancy) that those that do not (Hernandez et al., 2009), such as smooth muscle cells.

(2). MR-induced M-channel closure in neurons enhances their excitability and facilitates repetitive firing by producing membrane depolarization, increasing input resistance and reducing action potential threshold. However, in central neurons, the channels are notably concentrated in axons, at the axon initial segment and/or nodes of Ranvier. These are the sites of action potential initiation and propagation. Here, the co-localization of the $\mathrm{K}_{\mathrm{v}} 7$ channels with the $\mathrm{Na}^{+}$channels allows the former to exert a fine control over the action potential threshold (Schwarz et al, 2006; Shah et al., 2008). In hippocampal mossy fibres these axonal $\mathrm{K}_{\mathrm{v}} 7$ channels are co-localized with muscarinic M1Rs, allowing control of axonal M-currents by cholinergic afferents (Martinello et al., 2015).

(3). The muscarinic receptor responsible for $\mathrm{M}$ channel inhibition in sympathetic neurons is the $M_{1} R$ in both rat (Marrion et al., 1989; Bernheim et al., 1992) and mouse (Hamilton et al., 1997). Available evidence suggests that muscarinic inhibition of M-channels in rat central neurons is also mediated primarily by $M_{1} R s$ (striatal neurons: Shen et al., 2005) though not in mouse hippocampal neurons (Rouse et al., 2000) (but see Dasari \& Gulledge, 2011, for some contrary inferences).

(4). As pointed out in $\mathbf{2 . 1}$ above, $\mathrm{K}_{M}$ inhibition in sympathetic neurons results from hydrolysis and depletion of PIP2 (section 2.1). This also applies to some central neurons (e.g., Shen et al., 2005). Direct evidence for such depletion using the PIP2 binding probe Tubby (see Fig.1B) has been obtained in isolated hippocampal neurons (Nelson et al., 2008). However, other (additional or alternative) mechanisms of M1R inhibition have been described, including the following:

(a). Activation of PKC by diacylglycerol (generated by PIP2 hydrolysis) and consequent channel phosphorylation (Kosenko et al., 2012). This is facilitated by the binding of PKC to scaffold protein A-kinase Anchoring Protein AKAP79/150, which interacts with $K_{\mathrm{v}} 7.2$ protein and forms a structural bridge to the $M_{1} R$ (Kosenko et al., 2012). Genetic knockdown of AKAP150 in mice reduced MR suppression of M-current in sympathetic neurons and modified the nature of pilocarpine-induced seizures (Tunquist et al., 2008). AKAP150 also couples KCNQ channels and M1Rs to the transcriptional upregulation of $\mathrm{K}_{\mathrm{v}} 7$ channel expression (Zhang \& Shapiro, 2012). PKC-mediated M-current inhibition may be especially important in smooth muscle cells (Clapp et al., 1992) where it appears to be specifically directed at channels containing $\mathrm{K}_{\mathrm{v}} 7.5$ subunits (Bruggemann et al., 2014).

(b). M-channels are also very sensitive to inhibition by intracellular $\mathrm{Ca}^{2+}\left(\mathrm{IC}_{50} \sim 100 \mathrm{nM}\right.$ : Selyanko \& Brown, 1996), acting via channel-attached calmodulin (Gamper \& Shapiro, 2003). However, although $\mathrm{G}_{\mathrm{q}}$-coupled $\mathrm{MRs}$ are very effective in releasing $\mathrm{Ca}^{2+}$ from IP3- 
sensitive intracellular stores in non-neural cells (Caulfield, 1994; see also Fig.3), intracellular $\mathrm{Ca}^{2+}$-release does not appear to contribute to M1R-mediated inhibition of M-channels in neurons (Delmas \& Brown, 2005; Kruse et al., 2016). [Ca ${ }^{2+}$ release from intracellular stores does contribute to neuronal $\mathrm{K}_{\mathrm{M}}$ inhibition by some other $\mathrm{G}_{\mathrm{q}}$-coupled receptor (Gamper \& Shapiro, 2007), partly through a close association between the receptor and the $\mathrm{Ca}^{2+}$ stores (Delmas et al., 2002); this does not seem to normally apply to muscarinic receptors.]

Notwithstanding, a special role for $\mathrm{Ca}^{2+}$ in an unusually long-lasting M1R-induced inhibition of M-channels in the axons of dentate gyrus granule cells has recently been detected (Martinello et al., 2015) (see Fig. 5). This was secondary to an enhanced $\mathrm{Ca}^{2+}$ influx arising from a sustained enhancement of axonal Cav3.2 channel activity, leading to a rise in resting intra-axonal $\mathrm{Ca}^{2+}$ concentration. Thus, both the rise in $\mathrm{Ca}^{2+}$ and $\mathrm{M}$-current inhibition could be reversed by blocking Cav3 channels. The overall effect is to produce a persistent increase in excitability through a sustained reduction in axonal action potential threshold (Fig.5B).

\section{Fig 5 near here}

\subsubsection{Inhibition of EAG and related voltage-gated potassium channels.}

EAG (Ether-a-GoGo, $\mathrm{K}_{\mathrm{v}} 10$ ) (Whicher \& MacKinnon, 2016) is a voltage-gated channel that is widely expressed in brain, particularly in presynaptic terminals where it modulates $\mathrm{Ca}^{2+}$ influx and transmitter release (Mortensen et al., 2015). When expressed in HEK cells the channels are strongly inhibited by stimulating $\mathrm{M}_{1} \mathrm{Rs}$, probably by releasing $\mathrm{Ca}^{2+}$ from internal stores: EAG channels are inhibited by intracellular $\mathrm{Ca}^{2+}$ with an $\mathrm{IC}_{50} \sim 67 \mathrm{nM}$ (Stansfeld et al., 1996), probably via binding to calmodulin (CAM) and an interaction of Ca-CAM with the channel (Schönherr et al, 2000; Whicher \& MacKinnon, 2016).

Erg (EAG-related) channels (Kv11) form a component of the cardiac delayed rectifier current, but are also widely present in the brain where they help to regulate neuronal excitability (e.g. Hirdes et al., 2009). They can be inhibited by $M_{1} R s$, with a consequent increase in evoked action potential discharge and frequency (Selyanko et al., 1999). The mechanism is unclear: unlike EAG, erg inhibition does not appear to involve $\mathrm{Ca}^{2+}$ (Hirdes et al., 2004) and the channels are not very sensitive to PIP2 depletion (Kruse \& Hille, 2013; but see Bian et al., 2001). In interstitial cells of Cajal in the myenteric plexus, modulation of erg currents is suggested to involve protein kinase C (McKay and Huizinga , 2006); this has been shown to directly phosphorylate Erg (Cockerill et al., 2007).

\subsubsection{Inhibition of $K_{\text {ir }}$ inward rectifier $K^{+}$channels.}

Members of all families of the Kir inward rectifier potassium channels require phosphoinositides such as PIP2 for their activity and hence, like M-channels, are sensitive to PIP2 hydrolysis and depletion (Logothetis et al.,2015a).

$\boldsymbol{K}_{\text {ir }} \mathbf{2}$ channels have a high apparent affinity for PIP2 and are constitutively active at resting levels of membrane PIP2 (Stanfield et al., 2002). Hence they contribute to the resting membrane currents and resting potential of a number of neurons. They are essentially 
complementary in function to the M-current: thus, whereas the M-current produces an increasing outward current as the membrane depolarises, stabilizing the resting potential against inward depolarizing currents such as excitatory synaptic currents, Kir channels contribute an inward current as the cell is hyperpolarized, stabilizing the membrane potential against hyperpolarizing currents such as those carried by inhibitory synaptic potentials. In some neurons such as striatal neurons (Shen et al. 2007) $\mathrm{K}_{\mathrm{M}}$ and $\mathrm{K}_{\mathrm{ir}} 2$ co-exist; in others, such as sympathetic neurons, they appear largely confined to different neurons and thence help determine their differential firing properties (Wang \& McKinnon, 1995). In common with $\mathrm{K}_{\mathrm{M}}$ channels, $\mathrm{K}_{\mathrm{ir}} 2$ channels are strongly inhibited by stimulating M1Rs (Wang \& McKinnon, 1996). This is probably mediated by PIP2 depletion, and, in cortical neurons, leads to membrane depolarization, spontaneous action potential discharges and enhanced synaptic potential summation (Carr \& Surmeier, 2007). On the other hand, $\mathrm{K}_{\mathrm{ir}}$ inhibition by $\mathrm{M}_{1} \mathrm{Rs}$ in myenteric neurons may involve PKC-mediated phosphorylation (Uchimura \& North, 1990). Endogenous muscarinic inhibition of dendritic $\mathrm{K}_{\mathrm{ir}} 2$ channels in striatopallidal neurons may contribute to synaptic pruning in Parkinson's disease (Shen et al., 2007).

$\boldsymbol{K}_{i r} \mathbf{3}$ channels. These are subunits that form $\mathrm{G}$ protein-gated inward rectifier $\mathrm{K}^{+}$channels (GIRK channels). They also requires PIP2 for their activation (Huang et al., 1998; Logothetis et al., 2015a), and hence can be inhibited by $G_{q}$-coupled receptors such as $M_{1}, M_{3}$ or $M_{5}$ receptors. In partial accord with this, $\mathrm{GABA}_{B} \mathrm{R}$-activated GIRK currents in hippocampal neurons are inhibitable by activating endogenous $M_{1} / M_{3}$ receptors, but probably through a PIP2 $\rightarrow$ DAG $\rightarrow$ PKC-mediated change in GIRK-PIP2 "affinity" rather than PIP2 depletion (Sohn et al., 2007); a PKC-mediated inhibition of expressed GIRK1/GIRK4 ( $\left.\mathrm{K}_{\mathrm{ir}} 3.1 / 3.4\right)$ channels in frog oocytes by $M_{1}$ Rs was earlier shown by Hill \& Peralta (2001). This GIRK inhibition allows the possibility of cross-talk between GIRK-activating $\mathrm{M}_{2}$ or $\mathrm{M}_{4} R$ s and $\mathrm{G}_{\mathrm{q}}$-coupled MRs when both are expressed in the same cell. Thus, Kobrinsky et al (2000) found that co-activation of $\mathrm{M}_{3} \mathrm{Rs}$ in cardiac atrial cells caused a slow inhibition ("desensitization") of the GIRK current activated by $\mathrm{M}_{2} \mathrm{Rs}$ and that this required PLC-mediated PIP2 hydrolysis. (see Logothetis et al., 2015b, for further discussion).

\subsubsection{Inhibition of calcium-activated potassium currents ( $K_{c_{a}}$ currents).}

There are several types of $\mathrm{K}_{\mathrm{Ca}_{\mathrm{a}}}$ currents in neurons (Faber \& Sah, 2003). These are activated by a rise in intracellular $\mathrm{Ca}^{2+}$, usually by entry through voltage-gated $\mathrm{Ca}^{2+}$ channels, sometimes through $\mathrm{Ca}^{2+}$-permeable NMDA or nicotinic acetylcholine channels, or sometimes by release from intracellular stores. The different channels have different characteristic effects on the electrical activity and excitability of the cells. One of these, the so-called "slow after-hyperpolarizing current" or "SAHP" current (I $\left.I_{\text {SAHP }}\right)$ is especially sensitive to inhibition by $\mathrm{G}_{\mathrm{q}}$-coupled MRs (Nicoll, 1988). This current is generated by $\mathrm{Ca}^{2+}$ entry through voltagegated calcium channels opened during an action potential, increases slowly over hundreds of milliseconds and then declines over seconds (Fig.6). The slow onset probably reflects an indirect effect of $\mathrm{Ca}^{2+}$ mediated by one or more $\mathrm{Ca}^{2+}$-binding proteins (Andrade et al., 2012). The AHP-current exerts a strong inhibitory action on succeeding action potentials and so abbreviates the duration of a spike train induced by repetitive or prolonged stimuli (Fig. 6A). 
Stimulation of Gq-coupled MRs suppresses $\mathrm{I}_{\text {SAHP }}$ without affecting the preceding $\mathrm{Ca}^{2+}$ current (Fig.6B), and thereby facilitates repetitive firing (complementary to, though qualitatively different from, M-current inhibition). The molecular nature of the channels is unknown; a partial contribution by subunits of the $\mathrm{K}_{\mathrm{v}} 7$ family has been suggested (Andrade et al, 2012) but requires further substantiation. There is also some uncertainty from experiments on MRsubtype knock-out mice whether the inhibitory subtype is (Dasari \& Gulledge, 2011) or is not (Rouse et al, 2000) the $M_{1}$ subtype. The mechanism of inhibition is also unclear but there is some evidence to suggest that the activation process is sensitive to PIP2, and that Gqcoupled receptor inhibition might result from PIP2 depletion (Andrade et al, 2012).

\section{Fig 6 A,B near here}

Selective pharmacological or synaptic $M_{1} R$ activation has also been reported to inhibit $\boldsymbol{S K}$ (small-conductance) $\mathrm{K}_{\mathrm{Ca}}$ channels $\mathrm{K}_{\mathrm{Ca}} \mathbf{2}$ in CA1 hippocampal pyramidal neuron through a mechanism involving PKC activation (Buchanan et al., 2010). This has the functional effect of amplifying and prolonging the NMDAR-mediated component of the glutamatergic epsps, by reducing opposing SK voltage-shunting, and thereby enhancing Schaffer collateral-induced LTP. This accords with previous work showing that the SK channel blocker apamin can facilitate LTP induction (e.g., Stackman et al., 2002).

\subsubsection{Summary statement on $\mathrm{K}^{+}$channel inhibition.}

In essence, $\mathrm{K}^{+}$channels serve to stabilize the neuronal membrane potential and to reduce neuronal excitability. $\mathrm{K}^{+}$currents therefore act as repressor currents and their inhibition by muscarinic stimulation is a form of de-repression. The variety of $\mathrm{K}^{+}$channels reflects their subtle influence in setting the neuron's individual profile of excitable activity action potential threshold, duration, frequency and discharge pattern, The effects of muscarinic stimulation will therefore differ from one neuron to another, depending on the mix of $\mathrm{K}^{+}$channels present in the neuron, and their density and subcellular location. For this reason, it is not possible to provide trans-neuronal rules about the precise nature of muscarinic excitation or of its consequences. Likewise, the responsive $\mathrm{K}^{+}$channels vary in structure so no universal mechanism for muscarinic inhibition can be advanced. Many are indeed regulated by PIP2 (Gamper \& Shapiro, 2007) so may be susceptible to PIP2 depletion, but equally many are not (e.g., Kruse \& Hille, 2012). Other biochemical mechanisms for inhibition by $\mathrm{G}_{\mathrm{q}}$-coupled receptors so far suggested include phosphorylation by protein kinase $\mathrm{C}$ (or by other downstream kinases) or inhibition by $\mathrm{Ca}^{2+}$, but future research may yield very different mechanisms as seen with other channels and receptors (e.g, via $\beta$ arrestin rather than $\mathrm{G}_{\mathrm{q}} /{ }_{11}$ : Yang et al,. 2016)

\subsubsection{Inhibition and activation of chloride channels.}

(a). Inhibition. In rat sympathetic neurons $M_{1} R$ inhibition of $K_{M}$ channels is accompanied by inhibition of a resting $\mathrm{Cl}^{-}$current (Brown \& Selyanko, 1985a). This behaves as an additional "leak" current with a reversal potential more positive than that for $\mathrm{K}_{\mathrm{M}}$. This is because these cells have a high resting intracellular chloride concentration (Galvan et al., 1984), giving a 
chloride equilibrium potential $\mathrm{E}_{\mathrm{Cl}}$ around $-42 \mathrm{mV}$ when recorded with microelectrodes filled with chloride-free $\mathrm{K}^{+}$solutions (Adams \& Brown, 1974). Suppression of this current by a muscarinic agonist (or during synaptic stimulation: Brown \& Selyanko, 1985b) causes a hyperpolarization at membrane potentials positive to $E_{C I}$ ) (i.e., it opposes the effect of $K_{M}$ inhibition) but adds to the effect of $K_{M}$ inhibition negative to $E_{C l}$. Thus, when $K_{M}$ is inhibited and the cell enters spontaneous action potential firing mode, firing is reduced by muscarinic IcI inhibition (Brown \& Selyanko, 1985a,b). Neither the molecular identity of the channels nor their mechanism of inhibition is known.

\section{(b). Activation/enhancement.}

$\mathrm{M}_{1} \mathrm{R}$ stimulation can also enhance or activate a $\mathrm{Ca}^{2+}$-dependent $\mathrm{Cl}^{-}$current in sympathetic neurons (Marsh et al, 1995; Salzer et al., 2014). In the former case, the current appeared as a delayed but transient inward (depolarizing) current after a priming $\mathrm{Ca}^{2+}$ charge delivered through voltage-gated $\mathrm{Ca}^{2+}$ channels or nicotinic acetylcholine receptors, which was then strongly enhanced by $M_{1} R$ stimulation. The effect of the latter was replicated by PKC activation and prevented by PKC inhibitors. In the experiments by Salzer et al (2014), the current appeared as a more sustained inward current on application of a muscarinic agonist, which did not require a priming $\mathrm{Ca}^{2+}$ charge, but responded directly to PKC activation (so might have been sensitized to resting $\mathrm{Ca}^{2+}$ levels). It was identified as a $\mathrm{Cl}(\mathrm{Ca})$ current, probably carried by anoctamine channels, because it was inhibited by TMEM15A blockers. A muscarinic depolarization of interstitial cells of Cajal in the intestine, probably via $\mathrm{M}_{3} \mathrm{Rs}$, has also been attributed to activation of a $\mathrm{Cl}^{-}$current (Zhu et al., 2011).

\subsubsection{Activation of cation channels.}

There are numerous reports that $\mathrm{G}_{\mathrm{q}}$-coupled MRs can also activate a calcium-dependent nonselective (i..e., multi-ion) cation conductance channels in neurons. Its effects are variously manifest in a slow depolarization coupled with long-lasting action potential discharges (e.g., Shen \& North, 1992; Constanti et al., 1993; Delmas et al., 1996; Rahman \& Berger, 2011), a post-spike after-depolarization (ADP) and burst discharge (Caeser et al., 1993; Haj-Dahmane \& Andrade, 1998), or a long spike plateau potential (Fraser \& McVicar, 1996). Recent evidence suggest that the latter two events are triggered by activation of TRPC-containing cation channels (Struebing et al., 2001; Yan et al., 2009; Zhang et al., 2011), though Dasari et al (2013) were unable to detect any effect of TRPC1, TRPC5, TRPC6 or double TRPC5+6 gene deletions on prefrontal cortical neuron ADPs. MR activation of the TRPC5-based cation channel requires PLC activation and might arise from PIP2 hydrolysis and depletion since PIP2 itself inhibits TRPC5 channels (see Rohacs, 2014).

An alternative to a TRPC channel as a generator of the ADP, in some neurons such as hippocampal CA1 pyramidal neurons the inward current has been attributed to the expression of a persistent $\mathrm{Na}^{+}$current (Yue et al., 2005; see also Yamada-Hanff \& Bean, 2013). In this case, $M_{1} R$ stimulation does not seem to increase the cation current per se but enhances the ADP (and thereby facilitates burst-firing) or induces tonic firing (Yamada-Hanff \& Bean, 2013) by reducing the opposing effect of the $\mathrm{M}$-current in shunting the voltage change produced by 
the inward current. Currents through R-type (Cav2.3) $\mathrm{Ca}^{2+}$ channels also contribute to the ADP in hippocampal CA1 neurons (Park \& Spruston, 2012).

Two points relating to other cells and currents: (1). TRP channels (including TRPC5) may well contribute to the analogous MR-activated cation current in smooth muscle cells (see Zholos et al., 2004). (2). Colino \& Halliwell (1993) reported that MR activation by carbachol in CA1 hippocampal pyramidal neurons strongly potentiated the hyperpolarization-activated cation current $I_{0}$, carried by HCN subunits. Neither the receptor identity nor mechanism could be established, but $\mathrm{M}_{1} \mathrm{R}$ stimulation potentiates $\mathrm{HCN1}$ and $\mathrm{HCN} 2$ currents when reconstituted in oocytes (Pian et al., 2007). This was accompanied by a positive shift in HCN activation voltage, suggesting that it resulted from an increase in membrane PIP2 as might arise through activation of PI kinases.

\subsubsection{Inhibition of voltage-gated calcium channels.}

In addition to the rapid $\mathrm{G}_{\beta \gamma}$-mediated inhibition of $\mathrm{Cav} 2$ voltage-gated $\mathrm{Ca}^{2+}$ channels produced by $M_{2}$ or $M_{4}$ MRs referred to in $\mathbf{3 . 2}$ below, $M_{1} R$ stimulation produces a "slow", voltageinsensitive inhibition of certain neuronal Cav1 and Cav2 channels (Bernheim et al., 1992; Mathie et al., 1992; Hille, 1994; Bannister et al., 2002). This resembles $M_{1} R$ inhibition of $K_{v} 7$ channels in time course and dependence on a "diffusible" messenger (Bernheim et al, 1991; cf. Selyanko et al., 1992 for equivalent tests for a diffusible messenger for $\mathrm{K}_{\mathrm{M}}$ inhibition) (compare section 3.1. below). In accordance with this, subsequent work indicates that $M_{1} R$ sensitive $\mathrm{Ca}^{2+}$ channels also require PIP2 for full opening and that their muscarinic inhibition results primarily from PIP2 hydrolysis and depletion (Wu et al., 2002; Gamper et al., 2004; Michailidis et al., 2007; Suh et al., 2010; Vivas et al., 2013), although effects of lipids derived from PIP2 metabolism have also been suggested (Roberts-Crowley et al., 2009). Thus, there is a strong correlation between the Cav channel species sensitive to a voltage-activated PIP2 5phosphatase and those inhibited by $M_{1} R s$ (sensitive to both: Cav1.2,1.3, Cav2.1,2.2); not inhibited by either: Cav1.4, 2.3, 3.1, 3.2, 3.3; Suh et al., 2010). Although most work has been done with $M_{1} R s$, it is worth noting that, In reconstituted systems, neuronal L-type Cav1.2 channels are equally sensitive to $M_{1}, M_{3} \& M_{5} R s$ (Bannister et al.2002). Interestingly, and in contrast to the "fast" $\mathrm{M}_{4} \mathrm{R}$-mediated inhibition of $\mathrm{N}$-type Cav2.2 channels in sympathetic neurons (see 3.2 below), $M_{1} R$-mediated slow Cav2 inhibition does not appear to contribute to cholinergic inhibition of transmitter release from sympathetic neuron processes (Koh \& Hille, 1997). The principal short-term effect of inhibiting neuronal Cav channels may be to enhance post-synaptic excitability, by reducing $\mathrm{Ca}^{2+}$ influx and consequent activation of $\mathrm{K}_{\mathrm{Ca}}$ channels.

\section{Ion channel responses to $\mathrm{Gi} / \mathrm{Go}$-coupled $\mathrm{M}_{2} / \mathrm{M}_{4}$ receptors.}

$M_{2}$ and $M_{4}$ receptors couple primarily to the Pertussis toxin (PTx)-sensitive $G$ proteins $G_{i}$ and $G_{o}$ (Hulme et al., 1990; Caulfield, 1993). They produce two main effects in neurons: activation of inward rectifier $\left(\mathrm{K}_{\mathrm{i}} \mathrm{3}\right)$ potassium channels (also known as $\mathrm{G}$ protein-activated $\mathrm{K}^{+}$channels or GIRK channels), generating a postsynaptic inhibitory hyperpolarization; and inhibition of Cav2 family calcium currents, resulting principally in a depression of transmitter release (see Brown, 2010). The former is usually (but not invariably) produced by $M_{2}$ receptors coupling 
through $G_{i}$ proteins; calcium current inhibition may involve either $M_{2}$ or $M_{4}$ receptors, coupling primarily through $\mathrm{G}_{\text {o }}$.

\subsection{Activation of Kir potassium channels.}

The prototype for this effect is the response of cardiac atrial fibres to the activation of $M_{2} R s$ depicted in Fig. 2B. Here, the $M_{2} R s$ couple to the trimeric $G_{i}$ protein $\left(G_{\alpha i \beta \gamma}\right)$ and the released $\mathrm{G}_{\beta \gamma}$ interacts directly with the $\mathrm{K}^{+}$channel (a tetramer of $\mathrm{K}_{\mathrm{ir}} 3.1$ and $\mathrm{K}_{\mathrm{ir}} 3.4$ subunits) to increase its open probability (see Wickman \& Clapham, 1995; Yamada et al., 1998, Kubo et al., 2005, and Glaaser \& Schlesinger, 2015, for details). This hyperpolarizes the cell and contributes to the bradycardia produced by vagal stimulation. Because the interaction between $\mathrm{G}$ protein and channel is direct and does not require a diffusible second messenger, the sequence of events can be reproduced within the confines of a membrane patch (cf. 2.1.4 above).

The equivalent GIRK currents in neurons are usually carried by $\mathrm{K}_{\mathrm{ir}} 3.1 / 3,2$ heteromers (Kubo et al., 2005). Analogous inhibitory responses to MR activation have been frequently recorded in a variety of nerve cells, including: autonomic neurons (Hartzell et al., 1977; Dodd \& Horn, 1982; Fernandez et al., 1999); trigeminal sensory neurons (Kohlmeuer et al., 2006); central parabrachial neurons (Egan \& North, 1986); hippocampal CA1 interneurons (McQuiston \& Madison, 1999; Bell et al., 2013) and pyramidal neurons (Seeger and Alzheimer, 2001); cortical fast-spiking interneurons (Xiang et al., 1998); certain thalamic sensory neurons (Mooney et al., 2004; Beatty et al., 2005); and striatal cholinergic interneurons (Calabresi et al, 1998). Where characterized, the receptors involved appear to be primarily $M_{2}$ except in CA1 interneurons ( $M_{4}$ : Bell et al., 2013) and possibly striatum, where $M_{4}$ predominates (Hersch et al, 1994).

Interestingly, in rat sympathetic neurons which individually possess both $M_{2}$ and $M_{4}$ receptors, only the $M_{2} R$ appears capable of activating $K_{i r} 3.1 / 3.2$ whereas the $M_{4} R$ preferentially inhibited the Cav2 calcium current (see 3.2) (Fernandez et al., 1999). It was suggested that this might arise through some anatomical segregation of the $\mathrm{M}_{2}$ and $\mathrm{M}_{4}$ receptors with their cognate ion channels. Further experiments indicated that this segregation also extended to the cognate $G$ proteins, since $\alpha$-subunit antisense depletion revealed that $M_{2} R s$ preferentially signalled through endogenous $\mathrm{G}_{i}$ (Fernandez et al., 2001) whereas $\mathrm{M}_{4} \mathrm{Rs}$ signal to $\mathrm{Ca}^{2+}$ channels through endogenous $G_{\circ}$ (Delmas et al., 1998). Notwithstanding, in spite of the preferential coupling of $M_{2} R s$ and $M_{4} R s$ to different $\alpha$-subunits ( $\alpha$ i versus $\alpha o$ ), ion channel responses to both were ultimately conveyed by free $\beta \gamma$-subunits, since they could be replicated by over-expressing $\beta 1 \gamma 2$ subunits (Fig.7C) and inhibited by $\beta \gamma$-binding peptides (Delmas et al., 1998; Fernandez et al., 2001)

\section{Fug 7 near here}

3.1.1. Other muscarinic hyperpolarizations. Though most common, not all muscarinic hyperpolarizing responses are mediated by Kir activation, nor by $\mathrm{M}_{2}$ and/or $\mathrm{M} 4$ receptors. Thus Gulledge \& Stuart (2005) have described a transient cholinergic hyperpolarization of cortical pyramidal cells mediated by $M_{1}$ Rs. It was concluded that this resulted from PIP2 hydrolysis, IP3 formation, consequent release of $\mathrm{Ca}^{2+}$ and activation of $\mathrm{SK}\left(\mathrm{K}_{\mathrm{Ca}} 2\right)$ channels. A similar $\mathrm{Ca}^{2+}$-dependent muscarinic $\left(\mathrm{M}_{3} \mathrm{R}\right)$ hyperpolarization has been previously reported in 
cochlear hair cells (Shigemoto and Ohmori, 1991), dissociated hippocampal neurons (Wakamori et al., 1993) and midbrain dopaminergic neurons (Fiorillo and Williams, 2000). A muscarinic agonist has also been reported to activate an inwardly-rectifying $\mathrm{K}^{+}$-channel in molluscan neurons, but via a diffusible messenger rather than by direct $\mathrm{G}$ protein coupling (Bolshakov et al., 1993).

\subsection{Inhibition of Cav2 voltage-gated calcium channels.}

Muscarinic inhibition of voltage-gated calcium channels was first detected by Kuba \& Koketsu (1976) in the form of an atropine-sensitive reduction by acetylcholine of the $\mathrm{Ca}^{2+}$ action potential recorded in curarized frog sympathetic neurons bathed in isotonic $\mathrm{CaCl}_{2}$ solution. This has since been studied extensively in frog and rat sympathetic neurons, in neuronal cell lines and reconstituted systems, and also in some central neurons. The results converge in showing it to result from a direct effect of the $\beta \gamma$-subunits of a Pertussis-toxin sensitive $G$ protein (usually $G_{0}$ ) following its activation by $M_{2}$ or $M_{4}$ muscarinic receptors. This follows a general mechanism of transmitter modulation of Cav2 channels (Dolphin, 2003; Zamponi \& Currie, 2013), according to the scheme:

$$
\mathrm{A}+\mathrm{R} \rightarrow \mathrm{AR} \rightarrow \mathrm{AR}^{*}+\mathrm{G}_{\alpha \circ \beta_{\gamma}} \rightarrow \mathrm{G}_{\alpha \mathrm{o}-\mathrm{GTP}}+\mathrm{G}_{\beta_{\gamma}} \rightarrow \mathrm{Ca}_{\mathrm{V}} 2 \downarrow
$$

(cf. $\mathrm{K}_{\text {ir }}$ activation, section 1.2.1 above). Key features of the interaction are as follows.

a). The $\beta \gamma$-subunits interact directly with the $\operatorname{Cav} \alpha$-subunit with no second messenger involvement (De Waard et al., 1997). In consequence, inhibition is rapid, with a latency down to $10 \mathrm{msec}$ or so after strong receptor activation (Zhou et al, 1997).

b). Binding of $G_{\beta y}$ prolongs the time to first opening of the Cav2.2 channel following a depolarizing voltage step (Patil et al., 1996) and hence slows current onset (e.g., Bean, 1989). The channels are said to enter a "reluctant mode" (cf. Bean. 1989).

c). $G_{\beta \gamma}$-inhibition is voltage-dependent. Thus, increased depolarization (either with time or in amplitude) facilitates $G_{\beta \gamma}$ dissociation and relieves block (Ikeda, 1996). On removing depolarization, $G_{\beta \gamma}$ re-associates at a concentration-dependent rate (Elmslie \& Jones, 1994; Zhou et al., 1997; Delmas et al., 1998b). Hence Cav2 block will be relieved by action potential activity, to an extent dependent on the duration and frequency of the action potential discharge (Kasai,1992; Tosetti et al., 1999).

\subsubsection{Some particulars of muscarinic Cav2 inhibition.}

(1) In principal, Cav2 channels appear equally susceptible to inhibition by $M_{2}$ and $M_{4}$ receptors. Thus, endogenous Cav2.2 channels in differentiated rodent NG108-15 neuroblastoma $\mathrm{x}$ glioma hybrid cells were equally well inhibited (in a Pertussis toxin-sensitive manner) by expressed $M_{2}$ and $M_{4}$ receptors but were not affected by expressed $M 1$ and $M_{3} R s$ (Higashida et al., 1990). However in primary adult neurons there is a rather unpredictable selectivity for one or other of these receptors that is not necessarily dependent on their relative abundance. Thus in rat cervical sympathetic neurons Cav2.2 ( $\mathrm{N}$-type) channels are selectively inhibited by $M_{4} R s$ (Bernheim et al., 1992), even though $M_{2} R s$ are present in these neurons and are functionally effective in activating $\mathrm{K}_{\mathrm{ir}} 2$ channels (Fernandez et al, 1999; see 
3.1 above). The endogenous receptor responsible for the basal inhibition of the high voltageactivated $\mathrm{Ca}^{2+}$ current in differentiated NG108-15 mouse neuroblastoma $\mathrm{x}$ rat glioma cells is also the $\mathrm{M}_{4}$ receptor (Caulfield \& Brown, 1994). Curiously, however, Cav2.2 currents in the cervical sympathetic neurons in mice are preferentially inhibited by $\mathrm{M}_{2} \mathrm{Rs}$ and cholinergic inhibition is lost in $M_{2} R$ knock-out mice (Shapiro et al., 1999). $M_{2} R s$ might also mediate muscarinic inhibition of $\mathrm{Ca}^{2+}$ channels in rabbit sympathetic neurons (Mochida \& Kobayashi, 1986). $M_{4} R s$ also appear to be responsible for the Pertussis toxin-sensitive inhibition of high voltage-activated $\mathrm{Ca}^{2+}$ currents in rat intracardiac parasympathetic neurons (Cuevas \& Adams, 1997) (but see also Jeong \& Wurster 1997) while $M_{2}$ Rs have been identified as the likely subtype responsible for voltage-dependent Cav2.2 inhibition in rat stellate sympathetic neurons (Yang et al., 2006) and (most likely) for muscarinic inhibition of Cav2 currents in rat dorsal root sensory neurons (Haberberger et al., 1999; cf. Wanke et al., 1994).

Within the mammalian central nervous system, $\mathrm{M}_{2} \mathrm{Rs}$ are clearly responsible for the Pertussis toxin-sensitive muscarinic inhibition of the two high voltage activated Cav2.1 and Cav2.2 currents (Allen et al., 1993a) in cholinergic basal forebrain neurons (Allen \& Brown, 1993b). $\mathrm{M}_{2}$ Rs (Toselli \& Taglietti, 1995) are also likely to mediate the Pertussis toxin-sensitive muscarinic inhibition of high voltage-activated $\mathrm{Ca}^{2+}$-currents in hippocampal pyramidal neurons previously reported by Gahwiler \& Brown (1987) and Toselli \& Lux (1989). On the other hand, $\mathrm{M}_{4} \mathrm{Rs}$ are more likely to be responsible for the fast cholinergic inhibition of Cav2.2 and 2.1 ( $\mathrm{N}$ - and P-type) currents in principal neurons (Howe \& Surmeier, 1995) and cholinergic interneurons (Yan \& Surmeier, 1996) in the striatum.

(2). The subsequent events following M-receptor activation and Cav2 inhibition have been studied most intensively in cells from the rat superior cervical ganglion. Marrion et al (1987) first briefly reported that muscarine could inhibit a high voltage-activated $\mathrm{Ca}^{2+}$ current in dissociated adult sympathetic neurons. In a detailed study Wanke et al (1987) showed that inhibition involved N-type (Cav2.2) channels; that it involved current slowing; that muscarinic inhibition was replicated and occluded by GTP $\gamma \mathrm{S}$ [guanosine 5'-[ythio]triphosphate], and hence involved a G-protein); that inhibition was prevented by pretreatment with Pertussis toxin; and that inhibition was independent of protein kinases $A$ or C. Members of the Hille lab (Beech et al., 1992; Mathie et al., 1992; Bernheim et al., 1992) characterized the two forms of muscarinic inhibition of Cav2.2 channels in these neurons: $\mathrm{M}_{4} \mathrm{Rs}$ producing a rapid, voltage-dependent inhibition via a Pertussis-sensitive $\mathrm{G}$ protein (much as described by Wanke et al., 1987, though then-incorrectly attributed by Wanke to $M_{1} R s$ ); and $M_{1}$ Rs producing a slow, voltage-independent, Pertussis-insensitive but intracellular $\mathrm{Ca}^{2+}$-dependent inhibition as described in 2.1.4 above; the latter involving a diffusible messenger but the former more direct. Subsequently Herlize et al (1996), along with Ikeda (1996), showed that the $\beta \gamma$-subunits were responsible for the direct inhibition of Cav 2 channels by noradrenaline in these neurons. Delmas et al (1998a) subsequently

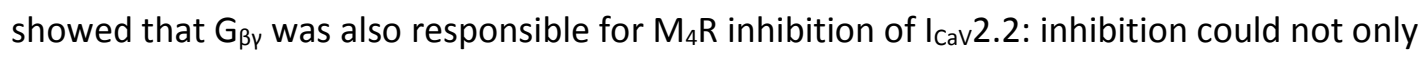
be replicated by over-expressing $\mathrm{G}_{\beta \gamma}$-subunits but also prevented by $\mathrm{G}_{\beta \gamma}$-binding peptides such as the $\beta$-adrenoceptor kinase ( $\beta A R K$ ) peptide. Delmas et al (1998a) also showed that the $G$-protein $G_{0}$, rather than $G_{i}$, was likely to be responsible for $M_{4} R$-mediated inhibition in these neurons since inhibition was prevented by injecting $G_{\alpha o}$ antibody or expressing antisense $G_{\alpha o} R N A$, but not by $G_{i}$ antibody or antisense. Similar mechanisms are likely to be 
involved in the fast muscarinic inhibition of Cav2 channels in central neurons (see, e.g., Toselli \& Lux, 1989; Yan \& Surmeier, 1995; Stewart et al., 1999).

\subsubsection{Physiological consequences of muscarinic inhibition of CaV2 channels.}

The principal physiological consequence of the inhibitory effect of $M_{2} / M_{4} R$ stimulation on Cav2 channels is to reduce the release of transmitter from the neuronal processes. Thus, the $\mathrm{M}_{4} \mathrm{R}-\mathrm{Ca}_{\mathrm{v}} 2.2$ inhibitory system recorded from sympathetic neuron somata is also expressed in the neurites of cultured sympathetic neurons, so that local application of a muscarinic agonist prevents the local release of noradrenaline from the varicosities of the neurites (measured by amperometry) in a Pertussis toxin-sensitive manner (Koh \& Hille, 1997). This is an example of a sympathetic nerve heteroreceptor (Fuder \& Muscholl, 1995).

In some equally innovative experiments, Stephens \& Mochida (2005), using ephaptic feedback cholinergic connexions of sympathetic neuron axons onto their somata to record transmitter release at single efferent synapses, showed that action potential-evoked release could be inhibited by presynaptic injection of free $\beta \gamma$-subunits. Mochida and Stephens went on to show that presynaptic injection of peptides designed to replicate the $G_{\beta \gamma}$-binding site of the Cav2.2 channel reduced both noradrenaline-induced somatic $\mathrm{Ca}^{2+}$-current inhibition and its inhibition of action potential-induced synaptic responses (Bucca et al., 2011). This is important in showing that, at this synapse at least, the effect of the $\beta \gamma$-subunits on transmitter release is indeed due to its action on the $\mathrm{Ca}^{2+}$ channels (and hence $\mathrm{Ca}^{2+}$ entry), rather than on subsequent steps in the release process as suggested by Blackmer et al (2001). Mochida's view is supported by Kajikawa et al (2001), who showed directly that $\beta \gamma$ subunits could indeed reduce the terminal $\mathrm{Ca}^{2+}$ current when injected into the large Calyx of Held terminals.

More important physiologically is muscarinic auto-inhibition, whereby acetylcholine released from cholinergic nerves feeds back to reduce its own subsequent release (Starke et al., 1989). This was first described by Dudar \& Szerb (1969) who noted that topical application of atropine strikingly increased the spontaneous release of acetylcholine from the cat cerebral cortex and also increased the additional release following stimulation of the subcortical brainstem reticular formation. This was originally interpreted to suggest the involvement of inhibitory cholinergic interneurons but this was discounted when Molenaar \& Polak (1970) confirmed the effect in $\mathrm{K}^{+}$-depolarized isolated cortical slices, even in the presence of tetrodotoxin. Following their observation that $\mathrm{M}_{2} \mathrm{R}$ stimulation inhibited $\mathrm{N}$ and $\mathrm{P} / \mathrm{Q} \mathrm{Ca}^{2+}$ currents in dissociated cholinergic basal forebrain neurons (see (1) above), Allen \& Brown (1996) studied this auto-inhibition in more detail by using a nicotinic receptor acetylcholine detector patch to record the action potential stimulated release of acetylcholine in real time from neurites of cholinergic basal forebrain neurons in culture. They showed that release could be rapidly and reversibly blocked by a muscarinic agonist, and (like the inhibition of the somatic $\mathrm{Ca}^{2+}$-current, resulted from activation of $\mathrm{M}_{2} \mathrm{Rs}$. Subsequent experiments using knock-out mice (Zhang et al., 2002) confirmed the role of $M_{2} R$ in cortical cholinergic auto-inhibition, but of M4Rs in the striatum. Allen (1999) went on to show that acetylcholine release from varicosities along the neurites was triggered by $\mathrm{Ca}^{2+}$ entry through the same $\mathrm{Ca}^{2+}$ channels (Cav2.1 and $\mathrm{Cav} 2.2 ; \mathrm{P} / \mathrm{Q}$ and $\mathrm{N}$ ) in approximately the same proportions as those carrying the muscarinic-sensitive somatic current. Finally, by 
recording from the basal forebrain neuronal soma at the same time as monitoring acetylcholine release from its neurites with a nicotinic receptor-rich myoball, Allen et al (2006) were able to show that single cultured basal forebrain neurons simultaneously released both glutamate (recorded as a feedback glutamatergic epsc in the soma) and acetylcholine. They then showed that activation of neuritic $\mathrm{M}_{2} \mathrm{Rs}$ reduced both glutamate and acetylcholine release, and that glutamate release (like acetylcholine release) was subject to inhibition by acetylcholine released from the same axon since the glutamatergic epsc recorded during repetitive somatic stimulation was progressively enhanced by atropine and reduced by an anticholinesterase. This has obvious implications for the use of anticholinesterases or other drugs to enhance cholinergic drive to the cortex from basal forebrain neurons.

\subsubsection{Inward rectifier $\mathrm{K}^{+}$channels and transmitter release.}

Apart from a possible difference in the species of Pertussis toxin-sensitive $G$ protein $\alpha$-subunit involved, the pathway leading to $\mathrm{M}_{2} / \mathrm{M}_{4}$ fast $\mathrm{Ca}^{2+}$-current inhibition is almost identical to that which triggers the opening of $\mathrm{K}_{\mathrm{ir}} 3 / \mathrm{GIRK} \mathrm{K}^{+}$channels. In principal, activation of $\mathrm{K}^{+}$channels could also reduce transmitter release, for example by introducing a leak conductance that acts as a voltage shunt to shorten the action potential waveform and reducing $\mathrm{Ca}^{2+}$ influx (much as vagal stimulation can do in the heart). Does this occur? The answer seems to be no. Thus Allen (1999) found no effect of $\mathrm{Ba}^{2+}$ ions (which blocked somatic $\mathrm{K}_{\mathrm{ir}}$ channels) on either resting acetylcholine release or muscarinic inhibition of such release from basal forebrain neurons. In other systems, Luscher et al (1997) found that $\mathrm{K}_{\mathrm{ir}} 3.2$ gene deletion eliminated the postsynaptic hyperpolarization of hippocampal pyramidal neurons produced by activating $\mathrm{G}_{\mathrm{i}} / \mathrm{G}_{0}$-coupled $\mathrm{GABA}_{B}, 5 \mathrm{HT} 1_{A}$ or adenosine $\mathrm{A} 1$ receptors without affecting their presynaptic inhibitory action. Further, Takahashi et al (1996) could not detect any outward current in the calyx of Held terminal after stimulating metabotropic glutamate receptors with sufficient intensity to annul the terminal $\mathrm{Ca}^{2+}$-current. Thus, it seem most likely that the $\mathrm{K}_{\mathrm{ir}} 3$ channels are not present in sufficient density in the nerve terminals so far studied to have any functional effect, or, if present, are unaffected by the $\mathrm{G}_{\mathrm{i}} / \mathrm{G}_{\mathrm{o}}$-coupled receptors present in those terminals (Takahashi et al, 1998) - a situation comparable to the differential coupling of muscarinic receptors to $\mathrm{Cav}_{\mathrm{v}}$ and $\mathrm{K}_{\mathrm{ir}}$ channels in sympathetic neurons (Fernandez et al, 1999).

\section{Final thoughts.}

While some general guidelines regarding the effects of MR stimulation on ion channels may be gleaned from the above, unfortunately it is not possible to predict in detail the events that will occur in a given cell type. For example, even for ion channels known to be regulated by PIP2 such as the $\mathrm{K}_{2 \mathrm{P}}$ channels, it is not possible without further experimentation to be sure whether the modulation of that channel by a $G_{q}$-coupled $M R$ results simply from the depletion of PIP2 or from an effect of one of the products of PIP2 hydrolysis. This question is important because, as indicted by Fig.3, one might expect very different sensitivities of different ion channels to a muscarinic agonist depending on 
how far downstream the transducer is from the receptor. To my knowledge, this question has not yet been systematically investigated.

It is equally difficult to predict $a b$ initio the consequences of MR stimulation, even at the level of the single neuron, let alone at the circuit or systems level. This is because many neurons possess multiple MRs, and may also possess multiple MR-sensitive ion channels. Thus, some autonomic neurons express at least four MRs (M1,2,3,4) (Hassall et a;., 1993; Brown et al., 1995), and in a neuron like the rat sympathetic neuron MR stimulation can modify the activity of at least 6 ion channels (TREK-1, $\mathrm{K}_{\mathrm{v}} 7, \mathrm{~K}_{\mathrm{ir}} 3, \mathrm{Cav} 1.2, \mathrm{Cav} 2.2, \mathrm{Cl}(\mathrm{Ca})$ ). To add complexity, MR-sensitive channels may be located in different subcellular compartments. Of those listed above, TREK-1, $\mathrm{K}_{\mathrm{ir}} 3, \mathrm{Cav} 1.2$ and probably $\mathrm{Cl}(\mathrm{Ca})$ channels seem to be somatodendritic in most neurons; $\mathrm{K}_{\mathrm{v}} 7$ channels may be somatodendritic in some neurons but are strongly concentrated in axons (at nodes of Ranvier in myelinated fibres and axon initial segments) in hippocampal and cortical pyramidal neurons and in motoneurons; and Cav 2 channels, though present in somatic regions, are concentrated at presynaptic terminals and subserve evoked transmitter release (e.g., Mochida et al., 2003).

This raises the question is there any relation between the distribution of MRs and the location of MR-sensitive ion channels. This is obviously the case for presynaptic $\mathrm{M}_{2}$ and $M_{4}$ receptors (see, e.g., Volpicelli \& Levey, 2004). Indeed the form of direct G-protein mediated coupling between $\mathrm{M}_{2} \mathrm{Rs}$ or $\mathrm{M}_{4} \mathrm{Rs}$ and Cav2 channels that leads to muscarinic inhibition of transmitter release virtually demands a close proximity between receptor and $\mathrm{Ca}^{2+}$ channel (Zhou et al., 1997). $\mathrm{Ca}^{2+}$ channels in chick calyx terminals are closely colocalized with their cognate $G$ protein $G_{\circ}$ (Li et al., 2004), and there are suggestions of an $\mathrm{M}_{2} \mathrm{R}-\mathrm{G}$ protein- $\mathrm{Ca}^{2+}$ channel complex involving RGS 12 as a scaffolding protein (Abramow-Newerly et al., 2006). The likelihood of equivalent receptor-G protein $-K_{\text {ir }}$ channel complexes has been referred to previously, as has the apparent necessity for separate complexes for $\mathrm{M}_{2} \mathrm{R}-\mathrm{G}_{\mathrm{i}}-\mathrm{K}_{\mathrm{ir}}$ and $\mathrm{M}_{4} \mathrm{R}-\mathrm{G}_{\mathrm{o}}-\mathrm{Cav}_{\mathrm{v}} 2$ interaction to explain their functional postsynaptic (somatic) segregation.

On the other hand there would seem to be no a priori reason for any such restrictive association between postsynaptic $\mathrm{M}_{1} \mathrm{Rs}$ and PIP2-gated ion channels such as $\mathrm{K}_{\mathrm{v}} 7$ channels to interpret their inhibition receptor-induced PIP2 hydrolysis, in which PIP2 depletion acts as a remote, diffusible second messenger. Indeed, the dynamics of $\mathrm{K}_{\mathrm{v}} 7$ inhibition in neurons can be substantially explained from observations on a reconstructed system in kidney cells without the need for any form of receptor-channel complex (Kruse et al., 2016). Notwithstanding, it is clear that the $M_{1} R$ does form a complex with the Kv7 channel underpinned by AKAP79/150 and that this serves to facilitate channel phosphorylation by PKC; this reduces channel affinity for PIP2, so sensitizing the channel to the reduction of PIP2 following $M_{1} R$ stimulation (Hoshi et al., 2003; Zhang et al., 2011; Kosenko et al., 2012). This might be regarded as a device to preferentially direct the receptor stimulus to the $\mathrm{K}_{\mathrm{v}} 7$ channel rather than to other PIP2sensitive channels (e.g., Kir, K2P, TRP, CaV) [a possibility that might warrant further study]. A molecular association between antibody-tagged AKAP150, $\mathrm{M}_{1} \mathrm{Rs}$ and $\mathrm{K}_{\mathrm{v}} 7.2 / 7.3$ heteromeric channels in sympathetic neurons has recently been confirmed by super- 
resolution microscopy (Zhang et al, 2016). This approach also revealed AKAP150-based functional multi-channel complexes in sensory neurons comprising $K_{v} 7$, TRPV1 and Cav1.2 channels; in appropriate cells these complexes might reasonably be expected to incorporate AKAP-binding $\mathrm{M}_{1} \mathrm{Rs}$, raising the possibility of other MR signalling microsystems. 


\section{References.}

Abramow-Newerly M, Roy AA, Nunn C, Chidiac P. (2006). RGS proteins have a signalling complex: interactions between RGS proteins and GPCRs, effectors, and auxiliary proteins. Cell Signal. 18:579591. PMID:16226429.

Adams PR, Brown DA. (1974). Actions of gamma-aminobutyric acid on sympathetic ganglion cells. J Physiol. 250:85-120. PMID:1177140

Allen TGJ (1999) The role of N-, Q- and R-type Ca2_ channels in feedback inhibition of ACh release from rat basal forebrain neurons. J Physiol (Lond) 515:93-107.

Allen TG, Abogadie FC, Brown DA. (2006). Simultaneous release of glutamate and acetylcholine from single magnocellular "cholinergic" basal forebrain neurons. J Neurosci. 26:1588-1595.

PMID:16452682

Allen TG, Sim JA, Brown DA. (1993a). The whole-cell calcium current in acutely dissociated magnocellular cholinergic basal forebrain neurones of the rat. J Physiol. 460:91-116. PMID: 7683720

Allen TG, Brown DA. (1993b). M2 muscarinic receptor-mediated inhibition of the Ca2+ current in rat magnocellular cholinergic basal forebrain neurones. J Physiol. 466:173-89.PMID: 8410690

Allen TGJ, Brown DA (1996) Detection and modulation of acetylcholine release from neurites of rat basal forebrain cells in culture. J Physiol (Lond) 492:453-466.

Andrade R, Foehring RC, Tzingounis AV. (2012) The calcium-activated slow AHP: cutting through the Gordian knot. Front Cell Neurosci. 6:47. PMID:23112761

http://journal.frontiersin.org/article/10.3389/fncel.2012.00047/full

Bannister RA, Melliti K, Adams BA. (2002). Reconstituted slow muscarinic inhibition of neuronal (Ca(v)1.2c) L-type Ca2+ channels. Biophys J. 83:3256-3267. PMID:12496094

Bean, BP. (1989). Neurotransmitter inhibition of neuronal calcium currents by changes in channel voltage dependence. Nature. 340:153-156. PMID:2567963

Beatty JA, Sylwestrak EL, Cox CL. (2009). Two distinct populations of projection neurons in the rat lateral parafascicular thalamic nucleus and their cholinergic responsiveness. Neuroscience. 162:155173. PMID:19393292.

Beech DJ, Bernheim L, Hille B. (1992). Pertussis toxin and voltage dependence distinguish multiple pathways modulating calcium channels of rat sympathetic neurons. Neuron. 8:97-106.

PMID:1346090

Bell LA, Bell KA, McQuiston AR. (2013). Synaptic muscarinic response types in hippocampal CA1 interneurons depend on different levels of presynaptic activity and different muscarinic receptor subtypes. Neuropharmacology. 73:160-173. PMID:23747570

Benians A, Nobles M, Hosny S, Tinker A (2005) Regulators of G-protein signaling form a quaternary complex with the agonist, receptor, and G-protein. A novel explanation for the acceleration of signaling activation kinetics. J.Biol.Chem. 280:13383-13394 PMID:15677457 
Benson, DM, Blitzer RD. Landau, EM. (1988). An analysis of the depolarization produced in guineapig hippocampus by cholinergic receptor stimulation. J Physiol. 404:479-496. PMID:3253439

Bernheim L, Beech DJ, Hille B (1991). A diffusible second messenger mediates one of the pathways coupling receptors to calcium channels in rat sympathetic neurons. Neuron. 6:859-867.

PMID:1647174

Bernheim L, Mathie A, Hille B. (1992). Characterization of muscarinic receptor subtypes inhibiting Ca2+ current and M current in rat sympathetic neurons. Proc Natl Acad Sci U S A. 89:9544-9548.

PMID: 1329101

Bian J, Cui J, McDonald TV. (2001). HERG K(+) channel activity is regulated by changes in phosphatidyl inositol 4,5-bisphosphate. Circ Res. 89:1168-1176. PMID:11739282

Bista P, Pawlowski M, Cerina M, Ehling P, Leist M, Meuth P, Aissaoui A, Borsotto M, Heurteaux C, Decher N, Pape HC, Oliver D, Meuth SG, Budde T. (2015). Differential phospholipase C-dependent modulation of TASK and TREK two-pore domain $\mathrm{K}+$ channels in rat thalamocortical relay neurons. $J$ Physiol. 593:127-144. PMID: 25556792

Blackmer T, Larsen EC, Takahashi M, Martin TFJ, Alford S \& Hamm H (2001). G protein $6 \gamma$ subunitmediated presynaptic inhibition: regulation of exocytotic fusion downstream of $\mathrm{Ca} 2+$ entry.

Science 292, 293-297. PMID:11303105

Bolshakov VYu, Gapon SA, Katchman AN, Magazanik LG. (1993). Activation of a common potassium channel in molluscan neurones by glutamate, dopamine and muscarinic agonist. J Physiol. 468:1133. PMID:7902868

Borroto-Escuela DO, Correia PA, Romero-Fernandez W, Narvaez M, Fuxe K, Ciruela F, Garriga P. (2011). Muscarinic receptor family interacting proteins: role in receptor function. J Neurosci Methods. 195:161-169. PMID: 21134400

Brown DA. (2007). The Skok legacy and beyond: molecular mechanisms of slow synaptic excitation in sympathetic ganglia. Neurophysiology (Kiev) 39, 243-247.

Brown DA (2010) Muscarinic acetylcholine receptors (mAChRs) in the nervous system: some functions and mechanisms. J. Molec. Neurosci. 41:340-346

Brown,DA. (2011). G-Proteins. Pp. 199-224 in Textbook of Receptor Pharmacology, Ed. J.C.Fpreman, T.Johansen \& A.J.Gibb. $3^{\text {rd }}$.Edition. CRC Press, Taylor \& Francis Group, Baton Rouge, FL, USA.

Brown DA, Adams PR. (1980) Muscarinic suppression of a novel voltage-sensitive $\mathrm{K}^{+}$-current in a vertebrate neurone. Nature 283:673-676. PMID: 6965523

Brown, DA, Buckley NJ, Caulfield, MP, et al., (1995) Coupling of muscarinic acetylcholine receptors to neural ion channels: closure of K+ channels. Pp 165-182 in:Molecular Mechanisms of Muscarinic Acetylcholine Receptor Function, J. Wess (ed.), R. G. Landes Comp.,Austin, TX

Brown DA, Passmore GM. (2009). Neural KCNQ (Kv7) channels. Br J Pharmacol. 156:1185-1195. PMID:19298256

Brown DA, Selyanko AA.(1985a) Two components of muscarine-sensitive membrane current in rat sympathetic neurones. J Physiol. 358:335-363. PMID:2580084 
Brown DA, Selyanko AA (1985b). Membrane currents underlying the cholinergic slow excitatory post-synaptic potential in the rat sympathetic ganglion. J Physiol. 365:365-87. PMID: 2411921

Brueggemann LI, Mackie AR, Cribbs LL, Freda J, Tripathi A, Majetschak M, Byron KL. (2014). Differential protein kinase C-dependent modulation of Kv7.4 and Kv7.5 subunits of vascular Kv7 channels. J Biol Chem. 289:2099-2111. PMID:24297175

Bucci G, Mochida S, Stephens GJ. (2011). Inhibition of synaptic transmission and G protein modulation by synthetic CaV2.2 $\mathrm{Ca}^{2}+$ channel peptides. J Physiol. 589:3085-3101. PMID:21521766

Buchanan K A, Petrovic MM, Chamberlain SE, Marrion NV, Mellor JR (2010) Facilitation of long-term potentiation by muscarinic $M_{1}$ receptors is mediated by inhibition of SK channels. Neuron $68,948-$ 963

Caeser M, Brown DA, Gähwiler BH, Knöpfel T. (1993). Characterization of a calcium-dependent current generating a slow afterdepolarization of CA3 pyramidal cells in rat hippocampal slice cultures. Eur J Neurosci. 5:560-569. PMID: 8261130

Calabresi P, Centonze D, Pisani A, Sancesario G, North RA, Bernardi G (1998).Muscarinic IPSPs in rat striatal cholinergic interneurones. J Physiol. 510:421-427. PMID:9705993

Carr DB, Surmeier DJ. (2007). M1 muscarinic receptor modulation of Kir2 channels enhances temporal summation of excitatory synaptic potentials in prefrontal cortex pyramidal neurons. J Neurophysiol. 97:3432-3438. PMID:17376848

Caulfield, MP. (1993). Muscarinic receptors--characterization, coupling and function. Pharmacol Ther. 58:319-379. PMID:7504306

Caulfield MP, Brown DA. (1991). Pharmacology of the putative M4 muscarinic receptor mediating Ca-current inhibition in neuroblastoma x glioma hybrid (NG 108-15) cells. Br J Pharmacol. 104(1):3944. PMID:1786516

Chen IS, Furutani K, Inanobe A, Kurachi Y. (2014) RGS4 regulates partial agonism of the M2 muscarinic receptor-activated K+ currents. J Physiol. 592:1237-1248. PMID:24421355

Chen X, Talley EM, Patel N, Gomis A, McIntire WE, Dong B, Viana F, Garrison JC, and Bayliss DA (2006) Inhibition of a background potassium channel by Gq protein $\alpha$-subunits. Proc Natl Acad Sci USA 103: 3422-3427. PMID: 16492788

Clapp LH, Sims SM, Singer JJ, Walsh JV Jr. (1992). Role for diacylglycerol in mediating the actions of ACh on M-current in gastric smooth muscle cells. Am J Physiol. 263:C1274-1281. PMID: 1476168.

Cockerill SL, Tobin AB, Torrecilla I, Willars GB, Standen NB, Mitcheson JS. (2007). Modulation of hERG potassium currents in HEK-293 cells by protein kinase C. Evidence for direct phosphorylation of pore forming subunits. J Physiol. 581:479-493. PMID:17363390

Cole AE, Nicoll RA. (1983). Acetylcholine mediates a slow synaptic potential in hippocampal pyramidal cells. Science. 221:1299-1301. PMID: 6612345

Colino A, Halliwell JV. (1993). Carbachol potentiates Q current and activates a calcium-dependent non-specific conductance in rat hippocampus in vitro. Eur J Neurosci. 5:1198-1209. PMID:8281323 
Constanti A, Bagetta G, Libri V. (1993). Persistent muscarinic excitation in guinea-pig olfactory cortex neurons: involvement of a slow post-stimulus afterdepolarizing current. Neuroscience. 56:887-904. PMID: 8284041

Cuevas J, Adams DJ. (1997). M4 muscarinic receptor activation modulates calcium channel currents in rat intracardiac neurons. J Neurophysiol. 78:1903-1912. PMID:9325359

Dasari S, Abramowitz J, Birnbaumer L, Gulledge AT. (2013). Do canonical transient receptor potential channels mediate cholinergic excitation of cortical pyramidal neurons? Neuroreport. 24:550-554. PMID: 23652155

Dasari S, Gulledge AT. (2011). M1 and M4 receptors modulate hippocampal pyramidal neurons. J Neurophysiol. 105:779-792. PMID:21160001

DeWaard, M., Liu, H., Walker, D., Scott, VES., Gurnett, CA, Campbell, KP. (1997). Direct binding of G-protein $\beta \gamma$ complex to voltage-dependent calcium channels. Nature 385, 446-450. PMID:9009193

Delmas P., Abogadie, FC., Dayrell, M, Haley, JE., Milligan, G., Caulfield, M.P., Brown, D.A. \& Buckley, N.J. (1998a). G-proteins and G-protein subunits mediating cholinergic inhibition of N-type calcium currents in sympathetic neurons. Eur.J.Neurosci., 10, 1654-1666. PMID:9751138

Delmas P, Brown DA, Dayrell M et al (1998b) On the role of endogenous G-protein beta gamma subunits in $\mathrm{N}$-type $\mathrm{Ca} 2+$ current inhibition by neurotransmitters in rat sympathetic neurones. J Physiol 506(Pt 2):319-29 PMID:11553279

Delmas P, Niel JP, Gola M. (1996) Muscarinic activation of a novel voltage-sensitive inward current in rabbit prevertebral sympathetic neurons. Eur J Neurosci. 8:598-610. PMID: 8963452

Delmas P, Wanaverbecq N, Abogadie FC, Mistry M, Brown DA. (2002). Signaling microdomains define the specificity of receptor-mediated InsP(3) pathways in neurons. Neuron. 2002 34:209-220. PMID: 11970863

Delmas P, Brown DA (2005). Pathways modulating neural KCNQ/M (Kv7) potassium channels. Nat Rev Neurosci 6, 850-862. PMID: 16261179

Dodd, J, Horn, J. P. (1982). Muscarinic inhibition of sympathetic C neurones in the bullfrog. The Journal of Physiology 334, 271-291. PMID:6602878

Dolphin AC. (2003). G protein modulation of voltage-gated calcium channels. Pharmacol Rev. 55:607-627 PMID:14657419

Doupnik CA. (2008).GPCR-Kir channel signaling complexes: defining rules of engagement. J Recept Signal Transduct Res. 2008;28(1-2):83-91. PMID:18437632

Doupnik CA, Davidson N, Lester HA, Kofuji P (1997) RGS proteins reconstitute the rapid gating kinetics of gbetagamma-activated inwardly rectifying K+ channels. Proc.Natl.Acad.Sci.U.S.A 94:10461-10466. PMID:9294233

Dudar JD, Szerb JC. (1969). The effect of topically applied atropine on resting and evoked cortical acetylcholine release. J Physiol. 203:741-762.PMID:5387031 
Egan, TM, North, RA. (1986). Acetylcholine hyperpolarizes central neurones by acting on an $\mathrm{M}_{2}$ muscarinic receptor. Nature 319, 405-407. PMID:2418362

Elmslie KS, Jones SW. (1994). Concentration dependence of neurotransmitter effects on calcium current kinetics in frog sympathetic neurones. J Physiol. 481:35-46. PMID:7853249

Enyedi P, Czirják G. (2010).Molecular background of leak K+ currents: two-pore domain potassium channels. Physiol Rev. 90:559-605. PMID:20393194

Faber ES, Sah P. (2003). Calcium-activated potassium channels: multiple contributions to neuronal function. Neuroscientist. 9:181-194. PMID: 15065814

Falkenburger BH, Jensen JB, Hille B. (2010a) Kinetics of M1 muscarinic receptor and G protein signaling to phospholipase $C$ in living cells. J Gen Physiol. 135:81-97. PMID:20100890

Falkenburger BH, Jensen JB, Hille B. (2010b) Kinetics of PIP2 metabolism and KCNQ2/3 channel regulation studied with a voltage-sensitive phosphatase in living cells. J Gen Physiol. 135: 99-114. PMID:20100890

Fernandez-Fernandez JM, Wanaverbecq N, Halley P, Caulfield MP, Brown DA. (1999) Selective activation of heterologously expressed $\mathrm{G}$ protein-gated $\mathrm{K}+$ channels by $\mathrm{M} 2$ muscarinic receptors in rat sympathetic neurones. J Physiol. 515: 631-637. PMID:10066893

Fernandez-Fernandez, JM., Abogadie FC., Milligan, G., Delmas, P. Brown, DA. (2001). Multiple pertussis toxin-sensitive $\mathrm{G}$ proteins can couple receptors to GIRK channels in rat sympathetic neurones when heterologously-expressed, but only native $G_{i}$ proteins do so in situ. Eur. J. Neurosci. 14, 283-292. PMID:11553279

Fidzinski P, Korotkova T, Heidenreich M, Maier N, Schuetze S, Kobler O, Zuschratter W, Schmitz D, Ponomarenko A, Jentsch TJ. (2015). KCNQ5 K(+) channels control hippocampal synaptic inhibition and fast network oscillations. Nat Commun. 6:6254. PMID: 25649132

Fiorillo CD, Williams JT. (2000). Cholinergic inhibition of ventral midbrain dopamine neurons. J Neurosci. 20:7855-7860. PMID:11027251

Fraser DD, MacVicar BA. 1996. Cholinergic-dependent plateau potential in hippocampal CA1 pyramidal neurons. J Neurosci 16:4113-4128. PMID:21645136

Fuder H, Muscholl E (1995). Heteroreceptor-mediated modulation of noradrenaline and acetylcholine release from peripheral nerves. Rev Physiol Biochem Pharmacol. 126:265-412 PMID:7886380

Fujita S, Inanobe A, Chachin M, Aizawa Y, Kurachi Y. (2000) A regulator of G protein signalling (RGS) protein confers agonist-dependent relaxation gating to a $\mathrm{G}$ protein-gated $\mathrm{K}+$ channel. J.Physiol. 526: 341-347. PMID:10896722

Fukuda K, Higashida H, Kubo T, Maeda A, Akiba I, Bujo H, Mishina M, Numa S (1988). Selective coupling with $\mathrm{K}+$ currents of muscarinic acetylcholine receptor subtypes in NG108-15 cells. Nature. 335:355-358. PMID:2843772. 
Gähwiler BH, Brown DA. (1987). Muscarine affects calcium-currents in rat hippocampal pyramidal cells in vitro. Neurosci Lett. 76:301-306. PMID:3587761

Galligan JJ, North RA, Tokimasa T. (1989), Muscarinic agonists and potassium currents in guinea-pig myenteric neurones. Br J Pharmacol. 96:193-203. PMID: 2924071

Galvan, M, Dorge A., Beck FRick, R. (1984). Intracellular electrolyte concentrations in rat sympathetic neurones measured with an electron microprobe. Pflugers Archiv 400, 274-279. PMID:6728648

Gamper N, Reznikov V, Yamada Y, Yang J, Shapiro MS. (2004). Phosphatidylinositol [correction] 4,5bisphosphate signals underlie receptor-specific Gq/11-mediated modulation of N-type $\mathrm{Ca} 2+$ channels. J Neurosci. 24:10980-10992. PMID:15574748

Gamper N, Shapiro MS (2003). Calmodulin mediates Ca2+-dependent modulation of M-type K+ channels. J Gen Physiol. 122:17-31. PMID:12810850

Gamper N, Shapiro MS. (2007) Regulation of ion transport proteins by membrane phosphoinositides. Nat Rev Neurosci. 8:921-934. PMID: 17971783

Glaaser IW, Slesinger PA (2015). Structural insights into girk channel function. Int Rev Neurobiol. 123:117-160. PMID:26422984

Greenwood IA, Ohya S. (2009), New tricks for old dogs: KCNQ expression and role in smooth muscle. Br J Pharmacol. 156:1196-1203. PMID:19751313

Gulledge AT, Stuart GJ (2005). Cholinergic inhibition of neocortical pyramidal neurons. J Neurosci. 25:10308-10320. PMID: 16267239

Haberberger R, Henrich M, Couraud JY, Kummer W (1999) Muscarinic M2-receptors in rat thoracic dorsal root ganglia. Neurosci Lett. 266:177-180. PMID: 10465702

Haj-Dahmane S, Andrade R (1998). Ionic mechanism of the slow afterdepolarization induced by muscarinic receptor activation in rat prefrontal cortex. J Neurophysiol.80:1197-1210. PMID:9744932

Hamilton SE, Loose MD, Qi M, Levey Al, Hille B, McKnight GS, Idzerda RL, Nathanson NM. (1997). Disruption of the $m 1$ receptor gene ablates muscarinic receptor-dependent $M$ current regulation and seizure activity in mice. Proc Natl Acad Sci U S A. 94:13311-13316. PMID: 9371842

Hansen HH, Waroux O, Seutin V, Jentsch TJ, Aznar S, Mikkelsen JD. (2008). Kv7 channels: interaction with dopaminergic and serotonergic neurotransmission in the CNS. J Physiol. 586:1823-1832. PMID:18174210

Hartzell, H.C., Kuffler, SW., Stickgold, R. ,Yoshikami, D. (1977). Synaptic excitation and inhibition resulting from direct action of acetylcholine on two types of chemoreceptors on individual amphibian parasympathetic neurones. The Journal of Physiology 271, 817-846. PMID:200739

Hassall CJ, Stanford SC, Burnstock G, Buckley NJ. (1993). Co-expression of four muscarinic receptor genes by the intrinsic neurons of the rat and guinea-pig heart. Neuroscience. 56:1041-1048.

PMID:8284034 
Heidenreich M, Lechner SG, Vardanyan V, Wetzel C, Cremers CW, De Leenheer EM, Aránguez G, Moreno-Pelayo MÁ, Jentsch TJ, Lewin GR. (2011). KCNQ4 K(+) channels tune mechanoreceptors for normal touch sensation in mouse and man. Nat Neurosci. 15:138-145. PMID:22101641

Herlitze S, Garcia DE, Mackie K, Hille B, Scheuer T, Catterall WA. (1996). Modulation of Ca2+ channels by G-protein beta gamma subunits. Nature. 380:258-262. PMID:8637576.

Hernandez CC, Falkenburger B, Shapiro MS. (2009). Affinity for phosphatidylinositol 4,5bisphosphate determines muscarinic agonist sensitivity of Kv7 K+ channels. J Gen Physiol. 134:437448. PMID:19858360

Hersch, SM, Gutekunst, CA., Rees, HD, Heilman, CJ, Levey,AI. (1994). Distribution of m1-m4 muscarinic receptor proteins in the rat striatum: light and electron microscopic immunocytochemistry using subtype-specific antibodies. J. Neurosci., 14: 3351-3363. PMID:8182478

Higashida H, Hashii M, Fukuda K, Caulfield MP, Numa S, Brown DA.(1990). Selective coupling of different muscarinic acetylcholine receptors to neuronal calcium currents in DNA-transfected cells. Proc Biol Sci. 242:68-74. PMID: 1980742

Hill JJ, Peralta EG. (2001). Inhibition of a Gi-activated potassium channel (GIRK1/4) by the Gqcoupled m1 muscarinic acetylcholine receptor. J Biol Chem. 276:5505-5510. PMID:11060307

Hille, B. (1994). Modulation of ion-channel function by G-protein-coupled receptors. Trends Neurosci. 17:531-536.

Hille B, Dickson E, Kruse M, Falkenburger B. (2014). Dynamic metabolic control of an ion channel. Prog Mol Biol Transl Sci. 123:219-247. PMID: 24560147

Hirdes W, Horowitz LF, Hille B. (2004). Muscarinic modulation of erg potassium current. J Physiol. 559:67-84. PMID:15235086

Hirdes W, Napp N, Wulfsen I, Schweizer M, Schwarz JR, Bauer CK. (2009). Erg K+ currents modulate excitability in mouse mitral/tufted neurons. Pflugers Arch. 459:55-70. PMID:19688350

Hodgkin Al, Katz B. (1949) The effect of sodium ions on the electrical activity of the giant axon of the squid. J Physiol. 108:37-77. PMID:18128147

Hoshi N, Zhang JS, Omaki M, Takeuchi T, Yokoyama S, Wanaverbecq N, Langeberg LK, Yoneda Y, Scott JD, Brown DA, Higashida H. (2003). AKAP150 signaling complex promotes suppression of the M-current by muscarinic agonists. Nat Neurosci. 6:564-571. PMID:12754513

Howe AR, Surmeier DJ. (1995).Muscarinic receptors modulate N-, P-, and L-type Ca2+ currents in rat striatal neurons through parallel pathways. J Neurosci. 15:458-469. PMID:7823150

Huang CL, Feng S, Hilgemann DW. (1998). Direct activation of inward rectifier potassium channels by PIP2 and its stabilization by Gbetagamma. Nature. 391:803-806. PMID: 9486652

Huang H, Trussell LO. (2011) KCNQ5 channels control resting properties and release probability of a synapse. Nat Neurosci. 14:840-847. PMID:21666672 
Hulme EC, Birdsall NJ, Buckley NJ. (1990). Muscarinic receptor subtypes. Annu Rev Pharmacol Toxicol. 30:633-673. PMID: 2188581

Ikeda, SR. (1996). Voltage-dependent modulation of N-type calcium channels by G-protein âã subunits. Nature 380, 255-258. PMID:8637575

Jensen JB, Lyssand JS, Hague C, Hille B (2009). Fluorescence changes reveal kinetic steps of muscarinic receptor-mediated modulation of phosphoinositides and Kv7.2/7.3 K+ channels. J Gen Physiol. 133:347-359. PMID: 19332618

Jentsch TJ. (2000). Neuronal KCNQ potassium channels: physiology and role in disease. Nat Rev Neurosci. 1:21-30. PMID: 11252765

Jeong SW, Ikeda SR. (1999). Sequestration of G-protein beta gamma subunits by different G-protein alpha subunits blocks voltage-dependent modulation of $\mathrm{Ca} 2+$ channels in rat sympathetic neurons. $J$ Neurosci. 19:4755-4761.

Jeong SW, Ikeda SR (2001) Differential regulation of G protein-gated inwardly rectifying K(+) channel kinetics by distinct domains of RGS8. J.Physiol. 535:335-347. PMID:11533127

Jeong SW, Wurster RD. (1997). Muscarinic receptor activation modulates Ca2+ channels in rat intracardiac neurons via a PTX- and voltage-sensitive pathway. J Neurophysiol. 78:1476-1490. PMID:9310437

Kajikawa Y, Saitoh N \& Takahashi T (2001). GTP-binding protein $\beta \gamma$ subunits mediate presynaptic calcium current inhibition by GABAB receptor. Proc Natl Acad Sci U S A 98,8054-8058.

PMID:11416164

Kasai H (1992). Voltage- and time-dependent inhibition of neuronal calcium channels by a GTPbinding protein in a mammalian cell line. J Physiol. 448:189-209. PMID: 1350637

Kleuss C, Scherubl H, Hescheler J, Schultz G, Wittig B. (1993). Selectivity in signal transduction determined by subunits of heterotrimeric $G$ proteins. Science 259:832-834

Knöpfel T, Vranesic I, Gähwiler BH, Brown DA. (1990). Muscarinic and beta-adrenergic depression of the slow Ca2(+)-activated potassium conductance in hippocampal CA3 pyramidal cells is not mediated by a reduction of depolarization-induced cytosolic $\mathrm{Ca} 2+$ transients. Proc Natl Acad Sci U S A.;87:4083-4087. PMID: 2161530

Kobrinsky E, Mirshahi T, Zhang H, Jin T, Logothetis DE. (2000). Receptor-mediated hydrolysis of plasma membrane messenger PIP2 leads to K+-current desensitization. Nat Cell Biol. 2:507-514. PMID:10934471

Koh DS, Hille B. (1997). Modulation by neurotransmitters of catecholamine secretion from sympathetic ganglion neurons detected by amperometry. Proc Natl Acad Sci U S A. 94:1506-1511. PMID: 9037083

Kohlmeier KA, Soja PJ, Kristensen MP. (2006). Disparate cholinergic currents in rat principal trigeminal sensory nucleus neurons mediated by $M 1$ and $M 2$ receptors: a possible mechanism for 
selective gating of afferent sensory neurotransmission. Eur J Neurosci. 23:3245-3258.

PMID:16820015

Kosenko A, Kang S, Smith IM, Greene DL, Langeberg LK, Scott JD, Hoshi N. (2012) Coordinated signal integration at the M-type potassium channel upon muscarinic stimulation. EMBO J. 31:3147-3156. PMID:22643219

Kruse M, Hille B. (2013) The phosphoinositide sensitivity of the K(v) channel family. Channels (Austin). 7:530-536. doi: 10.4161/chan.25816. PMID: 23907203

Kruse M, Vivas O, Traynor-Kaplan A, Hille B. (2016). Dynamics of phosphoinositide-dependent signaling in sympathetic neurons. J Neurosci. 36:1386-1400. PMID: 26818524

Kuba K, Koketsu K. (1976). The muscarinic effects of acetylcholine on the action potential of bullfrog sympathetic ganglion cells. Jpn J Physiol. 1976;26(6):703-16 PMID: 1088294

Kubo Y, Adelman JP, Clapham DE, Jan LY, Karschin A, Kurachi Y, Lazdunski M, Nichols CG, Seino S, Vandenberg CA. (2005).International Union of Pharmacology. LIV. Nomenclature and molecular relationships of inwardly rectifying potassium channels. Pharmacol Rev. 57:509-526. PMID: 16382105

Li Q, Lau A, Morris TJ, Guo L, Fordyce CB, Stanley EF (2004) A syntaxin 1, Galpha(o), and N-type calcium channel complex at a presynaptic nerve terminal: analysis by quantitative immunocolocalization. J Neurosci 24:4070-4081. PMID: 15102922

Lindner M, Leitner MG, Halaszovich CR, Hammond GR, Oliver D. (2011). Probing the regulation of TASK potassium channels by $\mathrm{PI} 4,5 \mathrm{P}_{2}$ with switchable phosphoinositide phosphatases. J Physiol. 589:3149-3162. PMID: 2154035

Logothetis DE, Petrou VI, Zhang M, Mahajan R, Meng XY, Adney SK, Cui M, Baki L. (2015a). Phosphoinositide control of membrane protein function: a frontier led by studies on ion channels. Annu Rev Physiol. 77:81-104. PMID: 25293526

Logothetis DE, Mahajan R, Adney SK, Ha J, Kawano T, Meng XY, Cui M. (2015b) Unifying Mechanism of Controlling Kir3 Channel Activity by G Proteins and Phosphoinositides. Int Rev Neurobiol. 2015;123:1-26. PMID:26422981

Lopes CM, Rohács T, Czirják G, Balla T, Enyedi P, Logothetis DE. (2005). PIP2 hydrolysis underlies agonist-induced inhibition and regulates voltage gating of two-pore domain $\mathrm{K}+$ channels. J Physiol. 564:117-129. PMID:15677683

Lüscher C, Jan LY, Stoffel M, Malenka RC, Nicoll RA (1997) G protein-coupled inwardly rectifying K+ channels (GIRKs) mediate postsynaptic but not presynaptic transmitter actions in hippocampal neurons. Neuron 19:687-695 PMID: 9331358

Madison, DV, Lancaster B, Nicoll, RA. (1987). Voltage clamp analysis of cholinergic action in the hippocampus. J. Neurosci 7: 733-741. PMID:559710

Marrion NV, Smart TG, Brown DA. (1987). Membrane currents in adult rat superior cervical ganglia in dissociated tissue culture. Neurosci Lett. 77:55-60. PMID:3601217 
Marrion NV, Smart TG, Marsh SJ, Brown DA. (1989). Muscarinic suppression of the M-current in the rat sympathetic ganglion is mediated by receptors of the M1-subtype. Br. J. Pharmacol., 98, 557-573. PMID:2819334

Marsh SJ, Trouslard J, Leaney JL, Brown DA (1995). Synergistic regulation of a neuronal chloride current by intracellular calcium and muscarinic receptor activation: a role for protein kinase $C$. Neuron. 15:729-737. PMID:7546751

Martinello K, Huang Z, Lujan R, Tran B, Watanabe M, Cooper EC, Brown DA, Shah MM. (2015). Cholinergic afferent stimulation induces axonal function plasticity in adult hippocampal granule cells. Neuron. 85:346-363. PMID:25578363

Mathie A. (2007) Neuronal two-pore-domain potassium channels and their regulation by G proteincoupled receptors. J Physiol. 578:377-385. PMID:17068099

Mathie A, Bernheim L, Hille B. (1992). Inhibition of N- and L-type calcium channels by muscarinic receptor activation in rat sympathetic neurons. Neuron. 8:907-914.PMID: 1316767

McKay CM, Huizinga JD. (2006) Muscarinic regulation of ether-a-go-go-related gene K+ currents in interstitial cells of Cajal. J Pharmacol Exp Ther. 319:1112-1123. PMID: 16946103

McQuiston AR, Madison DV. (1999). Muscarinic receptor activity has multiple effects on the resting membrane potentials of CA1 hippocampal interneurons. J Neurosci. 19:5693-5702. PMID: 10407010

Michailidis IE, Zhang Y, Yang J. (2007). The lipid connection-regulation of voltage-gated $\mathrm{Ca}^{2+}$ channels by phosphoinositides. Pflugers Arch.455:147-155.

Mochida S \& Kobayashi H (1986). Activation of M2 muscarinic receptors causes an alteration of action potentials by modulation of $\mathrm{Ca}$ entry in isolated sympathetic neurons of rabbits. Neurosci Lett 72, 199-204. PMID:2433647

Mochida S, Westenbroek RE, Yokoyama CT, Itoh K, Catterall WA. (2003). Subtype-selective reconstitution of synaptic transmission in sympathetic ganglion neurons by expression of exogenous calcium channels. Proc Natl Acad Sci U S A. 100:2813-2318. PMID:12601155

Molenaar, P. C., and R. L. Polak. (1970). Stimulation by atropine of acetylcholine release and synthesis in cortical slices from rat brain. Br. J. Pharmacol. 40: 406-417, 1970. PMID:5497792

Mooney DM, Zhang L, Basile C, Senatorov VV, Ngsee J, Omar A, Hu B. (2003) Distinct forms of cholinergic modulation in parallel thalamic sensory pathways. Proc Natl Acad Sci U S A. 101:320-324. PMID: 14691260

Moreau CJ, Dupuis JP, Revilloud J, Arumugam K, Vivaudou M. (2008) Coupling ion channels to receptors for biomolecule sensing. Nat Nanotechnol. 3:620-625. PMID:18839002

Mortensen LS, Schmidt H, Farsi Z, Barrantes-Freer A, Rubio ME, Ufartes R, Eilers J, Sakaba T, Stühmer W, Pardo LA. (2015). KV10.1 opposes activity-dependent increase in Ca2+ influx into the presynaptic terminal of the parallel fibre - Purkinje cell synapses. J Physiol. 593: 281-296. PMID:25344553

Neher E, Marty A, Fukuda K, Kubo T, Numa S. (1988). Intracellular calcium release mediated by two muscarinic receptor subtypes. FEBS Lett. 240:88-94. PMID:3192003 
Nelson CP, Nahorski SR, Challiss RA. (2008). Temporal profiling of changes in phosphatidylinositol 4,5-bisphosphate, inositol 1,4,5-trisphosphate and diacylglycerol allows comprehensive analysis of phospholipase C-initiated signalling in single neurons. J Neurochem. 107:602-615. PMID:18665913

Nicoll RA. (1988). The coupling of neurotransmitter receptors to ion channels in the brain. Science. 241:545-551. PMID: 2456612

Nobles $\mathrm{M}$, Benians A, Tinker A. Heterotrimeric $\mathrm{G}$ proteins precouple with $\mathrm{G}$ protein-coupled receptors in living cells. (2005).Proc Natl Acad Sci U S A. 102:18706-18711. PMID: 16352729

Osterrieder W, Noma A, Trautwein W. (1980). On the kinetics of the potassium channel activated by acetylcholine in the S-A node of the rabbit heart. Pflugers Arch. 386:101-109.PMID: 6253873.

Park JY, Spruston N. (2012). Synergistic actions of metabotropic acetylcholine and glutamate receptors on the excitability of hippocampal CA1 pyramidal neurons. J Neurosci. 32:6081-6091. PMID:22553015

Patil PG, de Leon M, Reed RR, Dubel S, Snutch TP, Yue DT. (1996). Elementary events underlying voltage-dependent G-protein inhibition of N-type calcium channels. Biophys J. 71:2509-2521. PMID:8913590

Pian P, Bucchi A, Decostanzo A, Robinson RB, Siegelbaum SA. (2007), Modulation of cyclic nucleotideregulated HCN channels by PIP(2) and receptors coupled to phospholipase C. Pflugers Arch. 455:125145. PMID: 17605039

Rahman J, Berger T. (2011). Persistent activity in layer 5 pyramidal neurons following cholinergic activation of mouse primary cortices. Eur J Neurosci. 34:22-30. PMID:21645136

Rivas-Ramírez P, Cadaveira-Mosquera A, Lamas JA, Reboreda A. (2015). Muscarinic modulation of TREK currents in mouse sympathetic superior cervical ganglion neurons. Eur J Neurosci. 42:17971807. PMID: 25899939

Robbins J, Caulfield MP, Higashida H, Brown DA. (1991). Genotypic m3-Muscarinic Receptors Preferentially Inhibit M-currents in DNA-transfected NG108-15 Neuroblastoma x Glioma Hybrid Cells. Eur J Neurosci. 3:820-824.PMID:12106468

Roberts-Crowley ML, Mitra-Ganguli T, Liu L, Rittenhouse AR. (2009). Regulation of voltage-gated Ca2+ channels by lipids. Cell Calcium. 45:589-601. PMID:19419761

Robbins J, Marsh SJ, Brown DA. (1993). On the mechanism of M-current inhibition by muscarinic $\mathrm{m} 1$ receptors in DNA-transfected rodent neuroblastoma $x$ glioma cells. J Physiol. 469:153-178.

PMID:8271196

Rohacs T. (2014). Phosphoinositide regulation of TRP channels. Handbuch. Exp Pharmacol. 223:11431176. membrane phosphoinositides. PMID: 24961984

Rolland JF, Henquin JC, Gilon P (2002). G protein-independent activation of an inward $\mathrm{Na}(+)$ current by muscarinic receptors in mouse pancreatic beta-cells. J Biol Chem. 277:38373-38380.

PMID: 12161432 
Rouse ST, Hamilton SE, Potter LT, Nathanson NM, Conn PJ. Muscarinic-induced modulation of potassium conductances is unchanged in mouse hippocampal pyramidal cells that lack functional M1 receptors. Neurosci Lett. 2000 Jan 7;278(1-2):61-4.PMID:10643801

Ruiz-Velasco V, Ikeda SR.(2000). Multiple G-protein betagamma combinations produce voltagedependent inhibition of $\mathrm{N}$-type calcium channels in rat superior cervical ganglion neurons. J Neurosci. 20:2183-2191.PMID: 10704493

Saitoh O, Kubo Y, Miyatani Y, Asano T, Nakata H. (1997) RGS8 accelerates G-protein-mediated modulation of K+ currents. Nature 390:525-529. PMID:9394004

Salzer I, Gafar H, Gindl V, Mahlknecht P, Drobny H, Boehm S. (2014). Excitation of rat sympathetic neurons via M1 muscarinic receptors independently of Kv7 channels. Pflugers Arch. 2014 466:22892303. PMID:24668449

Schönherr R, Löber K, Heinemann SH. (2000). Inhibition of human ether à go-go potassium channels by $\mathrm{Ca}(2+) /$ calmodulin. EMBO J. 19:3263-3271. PMID: 10880439

Schwarz JR, Glassmeier G, Cooper EC, Kao TC, Nodera H, Tabuena D, Kaji R, Bostock H. (2006). KCNQ channels mediate IKs, a slow K+ current regulating excitability in the rat node of Ranvier. J Physiol. 573:17-34. PMID:16527853

Seeger T, Alzheimer C. (2001). Muscarinic activation of inwardly rectifying $\mathrm{K}(+)$ conductance reduces EPSPs in rat hippocampal CA1 pyramidal cells. J. Physiol. 535, 383-396. PMID:11533131

Selyanko AA, Brown DA. (1996). Intracellular calcium directly inhibits potassium M channels in excised membrane patches from rat sympathetic neurons. Neuron. 16:151-162.PMID:8562079

Selyanko AA, Hadley JK, Wood IC, Abogadie FC, Delmas P, Buckley NJ, London B, Brown DA. (1999). Two types of $\mathrm{K}(+)$ channel subunit, Erg1 and $\mathrm{KCNQ} 2 / 3$, contribute to the M-like current in a mammalian neuronal cell. J Neurosci. 19:7742-7756. PMID: 10479678

Selyanko AA, Stansfeld CE, Brown DA (1992). Closure of potassium M-channels by muscarinic acetylcholine-receptor stimulants requires a diffusible messenger. Proc Biol Sci. 250:119-125. PMID:1361985

Shah MM, Migliore M, Valencia I, Cooper EC, Brown DA. (2008) Functional significance of axonal Kv7 channels in hippocampal pyramidal neurons. Proc Natl Acad Sci USA, 105:7869-7874.

PMID:18515424

Shapiro MS, Loose MD, Hamilton SE, Nathanson NM, Gomeza J, Wess J, Hille B. (1999). Assignment of muscarinic receptor subtypes mediating G-protein modulation of $\mathrm{Ca}(2+)$ channels by using knockout mice. Proc Natl Acad Sci U S A. 96:10899-10904. PMID:10485923

Shen KZ, North RA. (1992). Muscarine increases cation conductance and decreases potassium conductance in rat locus coeruleus neurones. J Physiol. 455:471-485. PMID: 1484360

Shen, W., Hamilton, S.E., Nathanson, N.M., and Surmeier, D.J. (2005). Cholinergic suppression of KCNQ channel currents enhances excitability of striatal medium spiny neurons. J. Neurosci. 25: 7449-7458. PMID:16093396 
Shen W, Tian X, Day M, Ulrich S, Tkatch T, Nathanson NM, Surmeier DJ. (2007). Cholinergic modulation of Kir2 channels selectively elevates dendritic excitability in striatopallidal neurons. Nat Neurosci. 10:1458-1466. PMID:17906621

Shigemoto T, Ohmori $\mathrm{H}$. Muscarinic receptor hyperpolarizes cochlear hair cells of chick by activating $\mathrm{Ca}(2+)$-activated K+ channels J Physiol. 1991 Oct;442:669-90 PMID:1798048

Sohn JW, Lim A, Lee SH, Ho WK (2007). Decrease in PIP(2) channel interactions is the final common mechanism involved in PKC- and arachidonic acid-mediated inhibitions of GABA(B)-activated K+ current. J Physiol. 582:1037-1046. PMID:17584838

Stackman RW, Hammond RS, Linardatos E, Gerlach A, Maylie J, Adelman JP, Tzounopoulos T. (2002). Small conductance $\mathrm{Ca} 2+$-activated $\mathrm{K}+$ channels modulate synaptic plasticity and memory encoding. J Neurosci. 22:10163-10171. PMID:12451117

Stanfield PR, Nakajima S, Nakajima Y. (2002). Constitutively active and G-protein coupled inward rectifier K ${ }^{+}$channels: Kir2.0 and Kir 3.0. Rev Physiol Biochem Pharmacol 145: 47-179. PMID:12224528

Stansfeld CE, Roper J, Ludwig J, Weseloh RM, Marsh SJ, Brown DA and Pongs O. (1996). Elevation of intracellular calcium by muscarinic receptor activation induces a block of voltage-activated rat ether-a-go-go channels in a stably-transfected cell line. Proc Natl Acad Sci USA 93: 9910-9914, 1996. PMID:790430

Starke K, Göthert M, Kilbinger H (1989). Modulation of neurotransmitter release by presynaptic autoreceptors. Physiol Rev. 69:864-989. PMID:2568648

Stephens GJ \&Mochida S (2005). G protein 6 subunits mediate presynaptic inhibition of transmitter release from rat superior cervical ganglion neurones in culture. J Physiol 563,765-776.

Stewart AE, Yan Z, Surmeier DJ, Foehring RC. (1999). Muscarine modulates Ca2+ channel currents in rat sensorimotor pyramidal cells via two distinct pathways. J Neurophysiol. 81:72-84. PMID: 9914268

Struebing C, Krapivinsky G, Krapivinsky L, Clapham DE. (2001).TRPC1 and TRPC5 form a novel cation channel in mammalian brain. Neuron 29:645-655. PMID:11301024

Suh BC, Hille B. (2002) Recovery from muscarinic modulation of $M$ current channels requires phosphatidylinositol 4,5-bisphosphate synthesis. Neuron. 35: 507-520.

Suh BC, Leal K, Hille B. (2010). Modulation of high-voltage activated $\mathrm{Ca}(2+)$ channels by membrane phosphatidylinositol 4,5-bisphosphate. Neuron.67:224-238. PMID:20670831

Sun Y, McGarrigle D, Huang XY. (2007). When a G protein-coupled receptor does not couple to a G protein. Mol Biosyst. 3:849-854 PMID: 18000562

Takahashi T, Forsythe ID, Tsujimoto T, Barnes-Davies M, Onodera,K. (1996) Presynaptic calcium current modulation by a metabotropic glutamate receptor. Science 274:594-597 PMID:849448

Takahashi T, Kajikawa Y, Tsujimoto T (1998) G-Protein-coupled modulation of presynaptic calcium currents and transmitter release by a GABAB receptor. J Neurosci 18:3138-3146 PMID: 9547222 
Telezhkin V, Brown DA, \& Gibb AJ. (2012). Distinct subunit contributions to the activation of M-type potassium channels by PI(4,5) $P_{2}$. J. Gen.Physiol. 140:41-53.

Toselli M, Lux HD. (1989). GTP-binding proteins mediate acetylcholine inhibition of voltage dependent calcium channels in hippocampal neurons. Pflugers Arch. 413:319-321. PMID: 2541406

Toselli M, Taglietti V. (1995) Muscarine inhibits high-threshold calcium currents with two distinct modes in rat embryonic hippocampal neurons. J Physiol. 483:347-65. PMID:7650608

Tosetti P, Taglietti V, Toselli M. (1999). Action-potential-like depolarizations relieve opioid inhibition of N-type Ca2+ channels in NG108-15 cells. Pflugers Arch. 437:441-448. PMID:9914401

Trautwein W, Osterreider W, Noma, A. (1980). Potassium channels and the sino-atrial node of the heart. Pp.5-22 in Drug Receptors and their Effectors, Ed.N.J.M.Birdsall, (New York: Macmillan).

Tunquist BJ, Hoshi N, Guire ES, Zhang F, Mullendorff K, Langeberg LK, Raber J, Scott JD. (2008). Loss of AKAP150 perturbs distinct neuronal processes in mice. Proc Natl Acad Sci U S A. 105:12557-12562. PMID: 18711127

Uchimura, N, North RA. (1990). Muscarine reduces inwardly rectifying potassium conductance in rat nucleus accumbens neurones. J Physiol. 422:369-380. PMID: 1693682

Veale EL, Kennard LE, Sutton GL, MacKenzie G, Sandu C, Mathie A (2007). G(alpha)q-mediated regulation of TASK3 two-pore domain potassium channels: the role of protein kinase $\mathrm{C}$. Mol Pharmacol. 71:1666-1675. PMID:17374744

Vivas O, Castro H, Arenas I, Elías-Viñas D, García DE. (2013). PIP ${ }_{2}$ hydrolysis is responsible for voltage independent inhibition of CaV2.2 channels in sympathetic neurons. Biochem Biophys Res Commun. 432:275-280. PMID:23396054

Volpicelli LA, Levey Al.(2004) Muscarinic acetylcholine receptor subtypes in cerebral cortex and hippocampus. Prog Brain Res. 145:59-66. PMID: 14650906

Wakamori M, Hidaka H, Akaike N. (1993). Hyperpolarizing muscarinic responses of freshly dissociated rat hippocampal CA1 neurones. J.Physiol. 463:585-604. PMID:7504109

Wanaverbecq N, Marsh SJ, Al-Qatari M, Brown DA (2003) The plasma membrane calcium-ATPase as a major mechanism for intracellular calcium regulation in neurones from the rat superior cervical ganglion. J Physiol 550:83-101.

Wang HS, McKinnon D. (1995). Potassium currents in rat prevertebral and paravertebral sympathetic neurones: control of firing properties. J Physiol. 485:319-335. PMID:7666361

Wang HS, McKinnon D. (1996). Modulation of inwardly rectifying currents in rat sympathetic neurones by muscarinic receptors. J Physiol. 492:467-478. PMID 9019543

Wang HS, Pan Z, Shi W, Brown BS, Wymore RS, Cohen IS, Dixon JE, McKinnon D.(1998) KCNQ2 and KCNQ3 potassium channel subunits: molecular correlates of the M-channel. Science. 282: 1890-1893 
Wanke E, Ferroni A, Malgaroli A, Ambrosini A, Pozzan T, Meldolesi J. (1987). Activation of a muscarinic receptor selectively inhibits a rapidly inactivated $\mathrm{Ca} 2+$ current in rat sympathetic neurons. Proc Natl Acad Sci U S A.84:4313-4317. PMID:2438697

Wanke E, Bianchi L, Mantegazza M, Guatteo E, Mancinelli E, Ferroni A. (1994). Muscarinic regulation of $\mathrm{Ca} 2+$ currents in rat sensory neurons: channel and receptor types, dose-response relationships and cross-talk pathways. Eur J Neurosci. 6:381-391. PMID: 8019675

Whicher JR, MacKinnon R. (2016). Structure of the voltage-gated K+ channel Eag1 reveals an alternative voltage sensing mechanism. Science. 353:664-669. doi: 10.1126/science.aaf8070. PMID:27516594

Wickman K, Clapham DE (1995) Ion channel regulation by G proteins. Physiol Rev. 75:865-885

Wilke BU, Lindner M, Greifenberg L, Albus A, Kronimus Y, Bünemann M, Leitner MG, Oliver D. (2014). Diacylglycerol mediates regulation of TASK potassium channels by Gq-coupled receptors. Nat Commun. 5:5540. doi: 10.1038/ncomms6540. PMID: 25420509

Winks JS, Hughes S, Filippov AK, Tatulian L, Abogadie FC, Brown DA, Marsh SJ (2005) Relationship between membrane phosphatidylinositol-4,5-bisphosphate and receptor-mediated inhibition of native neuronal M channels. J. Neurosci. 25: 3400-3413. PMID:15800195

Wu L, Bauer CS, Zhen XG, Xie C, Yang J. (2002) Dual regulation of voltage-gated calcium channels by Ptdlns(4,5)P2. Nature. 419:947-952. PMID:12410316

Xiang Z, Huguenard JR, Prince DA. (1998). Cholinergic switching within neocortical inhibitory networks. Science. 281:985-988. PMID:9703513

Yamada M, Inanobe A, Kurachi Y (1998). G protein regulation of potassium ion channels. Pharmacol Rev. 50:723-760.. PMID: 9860808

Yamada-Hanff J, Bean BP. (2013) Persistent sodium current drives conditional pacemaking in CA1 pyramidal neurons under muscarinic stimulation. J Neurosci. 33:15011-15021. PMID:24048831

Yan Z, Surmeier DJ. (1996). Muscarinic $(\mathrm{m} 2 / \mathrm{m} 4)$ receptors reduce $\mathrm{N}$ - and P-type Ca2+ currents in rat neostriatal cholinergic interneurons through a fast, membrane-delimited, G-protein pathway. J Neurosci. 16:2592-2604. PMID:8786435

Yan HD, Villalobos C,Andrade R. (2009). TRPC channels mediate a muscarinic receptor-induced afterdepolarization in cerebral cortex. J Neurosci 29: 10038-10046. PMID:19675237

Yang Q, Sumner AD, Puhl HL, Ruiz-Velasco V. (2006). M(1) and M(2) muscarinic acetylcholine receptor subtypes mediate $\mathrm{Ca}(2+)$ channel current inhibition in rat sympathetic stellate ganglion neurons. J Neurophysiol. 96:2479-2487. PMID: 17005606

Yang S, Ben-Shalom R, Ahn M, Liptak AT, van Rijn RM, Whistler JL, Bender KJ.(2016) $\beta$-Arrestindependent dopaminergic regulation of calcium channel activity in the axon initial segment. Cell Rep. 16:1518-1526. PMID: 27452469 
Yue C, Remy S, Su H, Beck H, and Yaari Y. (2005). Proximal persistent $\mathrm{Na}^{+}$channels drive spike afterdepolarizations and associated bursting in adult CA1 pyramidal cells. J Neurosci 25: 97049720. PMID:16237175

Zaika O, Zhang J, Shapiro MS (2011) Combined phosphoinositide and Ca2_signals mediating receptor specificity toward neuronal Ca2_ channels. J Biol Chem 286:830-841.

Zamponi GW, Currie KP. (2013). Regulation of $\mathrm{Ca}(\mathrm{V}) 2$ calcium channels by $\mathrm{G}$ protein coupled receptors. Biochim Biophys Acta. 1828:1629-43. PMID:23063655

Zhang H, Craciun LC, Mirshahi T, Rohacs T, Lopes CM, Jin T, Logothetis DE.(2003). PIP(2) activates KCNQ channels, and its hydrolysis underlies receptor-mediated inhibition of $\mathrm{M}$ currents. Neuron. 37: 963-975

Zhang J, Shapiro MS. (2012) Activity-dependent transcriptional regulation of M-Type (Kv7) K(+) channels by AKAP79/150-mediated NFAT actions. Neuron. 76:1133-1146. doi: 10.1016/j.neuron.2012.10.019. PMID: 23259949

Zhang J, Bal M, Bierbower S, Zaika O, Shapiro MS. (2011). AKAP79/150 signal complexes in G-protein modulation of neuronal ion channels. J Neurosci. 31:7199-7211. PMID:21562284

Zhang J, Carver CM, Choveau FS, Shapiro MS. (2016). Clustering and functional coupling of diverse ion channels and signaling proteins revealed by super-resolution STORM microscopy in neurons. Neuron. 92:461-478. PMID: 27693258

Zhang Q, Pacheco MA, Doupnik CA. (2002) Gating properties of GIRK channels activated by Galpha(o)- and Galpha(i)-coupled muscarinic $m 2$ receptors in Xenopus oocytes: the role of receptor precoupling in RGS modulation. J Physiol. 545:355-373. PMID: 12456817

Zhang W, Basile AS, Gomeza J, Volpicelli LA, Levey AI, Wess J. (2002) Characterization of central inhibitory muscarinic autoreceptors by the use of muscarinic acetylcholine receptor knock-out mice. J Neurosci. 22:1709-1717. PMID:5497792

Zhang Z, Reboreda A, Alonso A, Barker PA, Séguéla P. (2011). TRPC channels underlie cholinergic plateau potentials and persistent activity in entorhinal cortex. Hippocampus. 21:386-397. PMID:20082292

Zholos AV, Zholos AA, Bolton TB. (2004). G-protein-gated TRP-like cationic channel activated by muscarinic receptors: effect of potential on single-channel gating. J Gen Physiol. 123:581-598. PMID: 1511164

Zhou J, Shapiro MS, Hille B. (1997) Speed of Ca2+ channel modulation by neurotransmitters in rat sympathetic neurons. J Neurophysiol. 77:2040-2048. PMID: 9114253

Zhu MH, Sung IK, Zheng H, Sung TS, Britton FC, O'Driscoll K, Koh SD, Sanders KM (2011) Muscarinic activation of Ca2+-activated $\mathrm{Cl}$ - current in interstitial cells of Cajal. J Physiol 589:4565-4582 PMID:21768263 
Figure legends.

Fig.1. Time-course of $\mathrm{M}_{1} \mathrm{R}$-mediated $\mathrm{M}$-type $\mathrm{K}^{+}$channel inhibition in rat superior cervical sympathetic (SCG) neurons in relation to: A PIP2 hydrolysis; and B loss of PIP2 from the plasma membrane.

Cells were held at a depolarized membrane potential to generate a steady outward M-current. $10 \mu \mathrm{M}$ oxotremorine-M (Oxo-M) was applied to activate the $\mathrm{M}_{1}$ receptors and reduce the M-current (shown by the downward deflexions).

In A, the hydrolysis of PIP2 was monitored simultaneously with the change in current from the shift of the fluorescent probe GFP-PLC $\delta$-PH from the membrane (where it binds to PIP2) to the cytosol (where it binds to IP3) as shown by the images above. The increase in cytosolic fluorescence is superimposed in red on the current trace. Responses to two applications of Oxo-M were recorded [Part-published in Delmas \& Brown, 2005 (see Winks et al, 2005, for technical details)]

B shows averaged data from SCG neurons (black symbols and lines) and tSA201 fibroblasts expressing M1Rs and Kv7.2/7.3 channel subunits blue data points). Top trace: normalized $\mathrm{K}_{\mathrm{M}}$ or $\mathrm{K}_{\mathrm{v}} 7.2 / 7.3$ currents Bottom trace: normalized membrane PIP2 levels reported using a FRET assay of the PIP2-binding probe Tubby. In all cases current responses are closely aligned with changes in PIP2 hydrolysis or depletion. The faster recovery in SCG neurons (time-constant $\sim 42 \mathrm{sec}$ ) than in tsA cells (112 sec) was attributed to faster phosphorylation of phosphatidylinositol by PI4-kinase. [Adapted with permission from Kruse et al., 2016.]

Fig. 2. Speed of some $M R$-induced $K^{+}$channel responses following fast receptor activation.

A. $\mathrm{M}_{1} \mathrm{R}$-induced $\mathrm{M}$-current inhibition in a neuron in an isolated rat superior cervical sympathetic ganglion induced by synaptically-released acetylcholine recorded at $24^{\circ} \mathrm{C}$ (upper record) and $34^{\circ} \mathrm{C}$ (lower record). The preganglionic cholinergic nerve was stimulated 8 times (upper record) or 4 times (lower record) at $40 \mathrm{~Hz}$. The initial downward deflexion of the current trace (marked " $\mathrm{N}$ ") is a partly curare-blocked inward nicotinic current; this signals the postsynaptic delivery of the released acetylcholine. The second inward current marked " $\mathrm{M}$ " signals the loss of outward current due to M-channel closure. The time between the nicotinic current and the onset of the muscarinic current was about $2 \mathrm{~s}$ at $24^{\circ} \mathrm{C}$ and about $250 \mathrm{~ms}$ at $34^{\circ} \mathrm{C}$ (shown in the expanded record at $34^{\circ} \mathrm{C}$ ). [Adapted from Fig. 4 in Brown, 2007.]

B. $\mathrm{M}_{2} \mathrm{R}$-induced outward $\mathrm{K}^{+}$current in an isolated rabbit cardiac sino-atrial node cell. Receptors were activated by two iontophoretic ejections of acetylcholine from a micropipette placed about $2 \mu \mathrm{m}$ above the cell membrane (each pulse 33ms, $50 \mathrm{nA}$ ). Temperature $36^{\circ} \mathrm{C}$. The latency to $\mathrm{K}^{+}$cuurent onset from the second ejection artefact was about 50 msec. [From Fig.7.14 in Brown, 2011, derived with permission from Trautwein et al., 1980.]

Fig.3. Downstream signalling following M1R stimulation M-channel ( $\left.K_{v} 7.2 / 7.3\right)$ inhibition, based on experimental measurements and modelling in tsA-201 cells. [Adapted with permission from Hille et al., 2014] 
Ordinates: normalized response. Abscissae: muscarinic ligand concentration (multiples of $K_{D}$, the dissociation equilibrium constant for bind to the sum of all receptor states)

Abbreviations:

R occupancy $=$ receptor occupancy for all receptor states $=\sum A R /\left(\sum R+\sum A R\right)$;

$\mathrm{G} \alpha-\mathrm{PLC}=$ activation of phospholipase $\mathrm{C} \beta$ (PLC) by $\mathrm{G}_{\mathrm{GTP}}$ formed following AR/G $\alpha \mathrm{q}_{\mathrm{GDP}} \beta \gamma$ interaction, measured by CFP- $\alpha$ /YFP-PLC FRET;

$\mathrm{PIP}_{2}=$ membrane phosphatidylinositol-4,5-bisphosphate, measured from membrane fluorescent GFP-PH-PLCD binding and translocation.

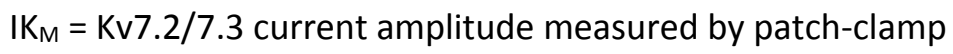

$\mathrm{IP}_{3}=$ inositol-1,4,5 trisphosphate, measured by binding of LIBRAvIII, a FRET reporter based on the ligand-binding domain of the rat IP3 receptor type III.

DAG = diacylglycerol, measured from the membrane binding of the FRET reporter based on the $\mathrm{C} 1$ domain of PKC $Y$

$\mathrm{Ca}^{2+}$ measured from Fura-2 fluorescence

Fig. 4. Muscarinic inhibition of TASK3 ( $\left.\mathrm{K}_{2 \mathrm{P}} 9.1\right)$, a standing outward "leak" potassium currents ("IKso") in cerebellar granule cells. [From Mathie, 2007, with permission]

A. The standing outward current (IKso, black line) is recorded by holding the cell at $-20 \mathrm{mV}$ and stepping back to $-60 \mathrm{mV}$ for $800 \mathrm{~ms}$. The current is inhibited by $10 \mu \mathrm{M}$ muscarine via M3Rs (red line).

B. Application of $10 \mu \mathrm{M}$ muscarine at the resting potential $(-85 \mathrm{mV})$ produced a depolarization and facilitated the generation of action potentials by $1 \mathrm{~Hz}, 100 \mathrm{pA}$ depolarizing current injections. Selected responses to current injections are shown on expanded timebase below.

Fig.5. Activation of $M_{1} R s$ in rat hippocampal dentate gyrus granule cells produces a persistent inhibition of the M-current in the granule cell mossy fibre axons. This leads to a fall in action potential threshold. It is caused by a persistent increase in axonal Cav3.2 activity and is prevented or reversed by blocking Cav channels. [Adapted from Martinello et al., 2015; q.v. for technical details.]

A. Upper record. Families of axonal membrane currents recorded with a somatic patch electrode before (control), $10 \mathrm{~min}$ after addition of $1 \mu \mathrm{M}$ oxotremorine-M, then 10 and 20 min after oxotremorine-M washout, and finally after adding $3 \mu \mathrm{M}$ XE991, an $\mathrm{M}$ channel blocker. The cell membrane potential was held at - $20 \mathrm{mV}$ to pre-activate $\mathrm{M}$ current $\left(I_{\mathrm{KM}}\right)$ then commanded to $-110 \mathrm{mV}$ on $10 \mathrm{mV}$ steps tp deactivate $\mathrm{I}_{\mathrm{KM}}$

Lower record. Same protocol as in upper record except that 500 nM TTA-P2, a Cav3 calcium channel blocker, was added before adding oxotremorine-M and left in the bathing solution thereafter. Note that oxotremorine-M no longer inhibited the membrane current whereas XE991 still blocked the current.

B Effects of oxotremorine-M on action potential threshold. Under control conditions (left- side plot), the reduction in threshold of around $6 \mathrm{mV}$ persisted for at least $20 \mathrm{~min}$ after washout. When the Cav3 channel blocker TTA-P2 was included in the washout solution the threshold substantially recovered during the washout period. 
Fig. 6. Muscarinic inhibition of the slow $\mathrm{Ca}^{2+}$-dependent after-hyperpolarization (AHP) and its underlying current ( $\mathrm{I}_{\mathrm{AHP}}$ ) in hippocampal pyramidal cells.

A. Microelectrode recordings from a CA1 pyramidal cell in an intact isolated rat hippocampal slice. The upper record shows the slow AHP following a depolarizing current injection (at $A$ ). On a slower time-base, with hyperpolarizing current injections to measure input resistance (at $B)$, acetylcholine $(\mathrm{ACH}, 200 \mu \mathrm{M})$ depolarized the neuron increased cell firing and increased its input resistance. The membrane potential was restored with current injection (-d.c.) and suppressed the AHP triggered from the original resting potential (at $C$ ). These effects were reversed by $0.5 \mu \mathrm{M}$ atropine. (The depolarization and increased input were probably due to inhibition of $\mathrm{K}_{M}$ and $\mathrm{K}_{\text {leak }}$ currents). The lower record shows that the inhibition of the AHP is associated with an increase in the number of action potentials produced by a $600 \mathrm{~ms}$ depolarizing current injection. Other experiments showed that the AHP was activated by the entry of $\mathrm{Ca}^{2+}$ during the preceding depolarization. [From Cole \& Nicoll, 1983, with authors' permission].

B. Simultaneous microelectrode recordings of membrane current (upper records) and photodiode recordings of intracellular $\mathrm{Ca}^{2+}$ by Fura-2 fluorescence (middle records) from a CA3 pyramidal cell in an organotypic slice of the rat hippocampus. Lower records show the voltage commands ( $100 \mathrm{~ms}$ to $-5 \mathrm{mV}$ ) from $-55 \mathrm{mV}$ resting potential. The voltage step to $-5 \mathrm{mV}$ evokes an outward AHP current and a simultaneous $\mathrm{Ca}^{2+}$ increase. Muscarine $(0.25 \mu \mathrm{M})$ suppressed the outward AHP current but did not affect the $\mathrm{Ca}^{2+}$ transient. Note that the outward current reversed to an inward current in the presence of muscarine. This is the after-depolarizing (ADP) current (see section 2.1.3). [From Knoepfel et al., 1990] 
Fig.1

A
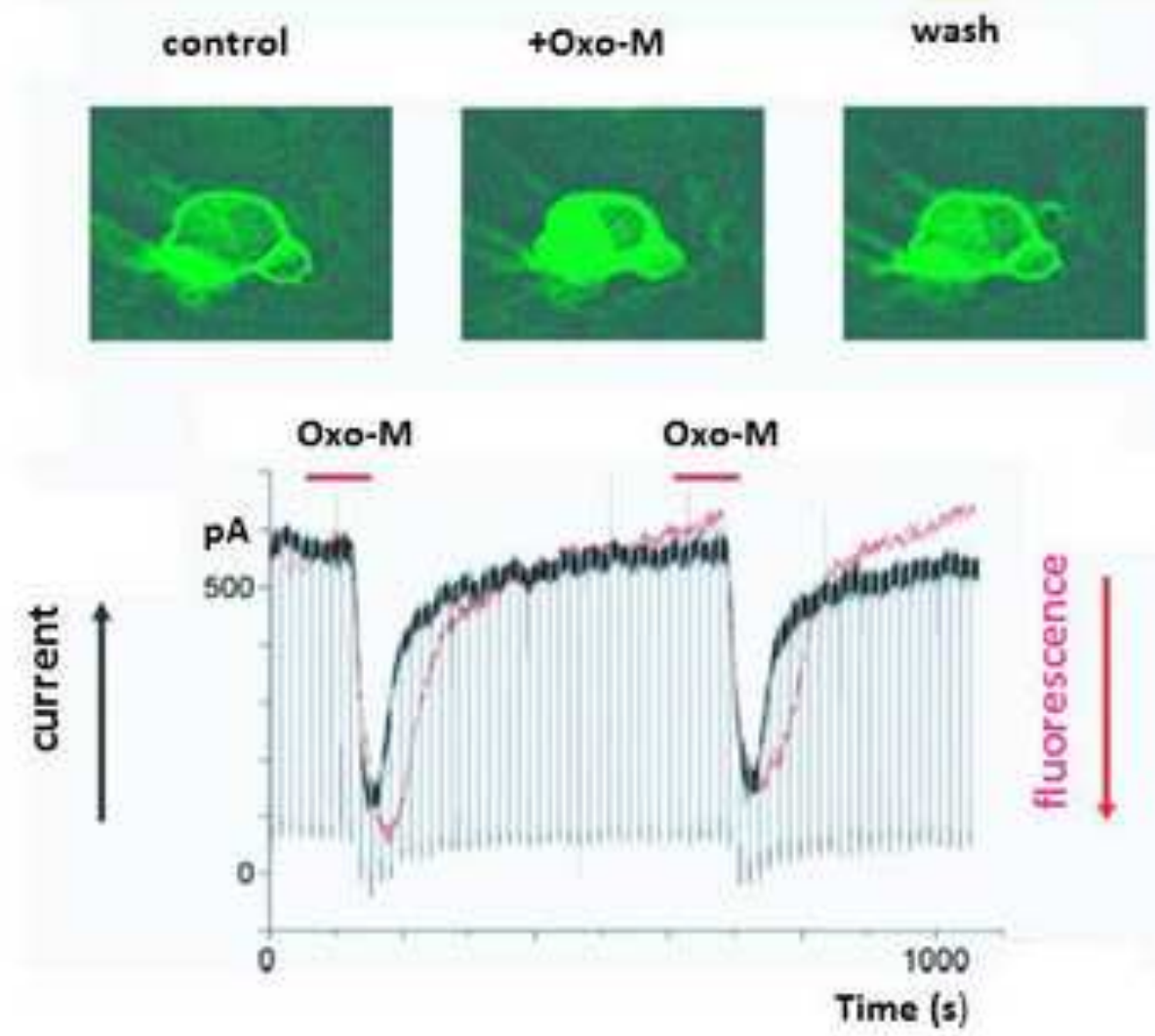

B
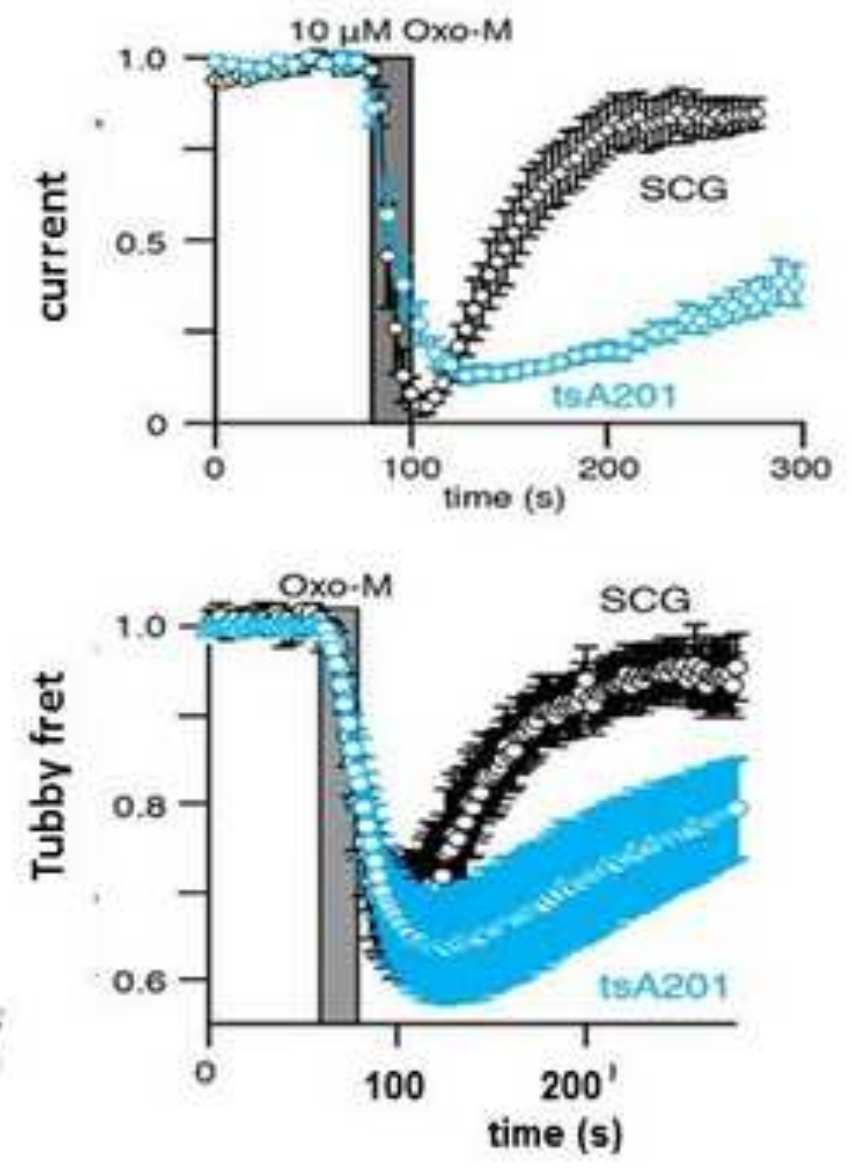


\section{Fig.2 A Rat symp neuron} $\mathrm{K}_{\mathrm{M}}$-current inhibition

$34^{\circ} \mathrm{C}$

B. Rabbit SA node Kir current activation

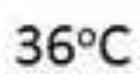

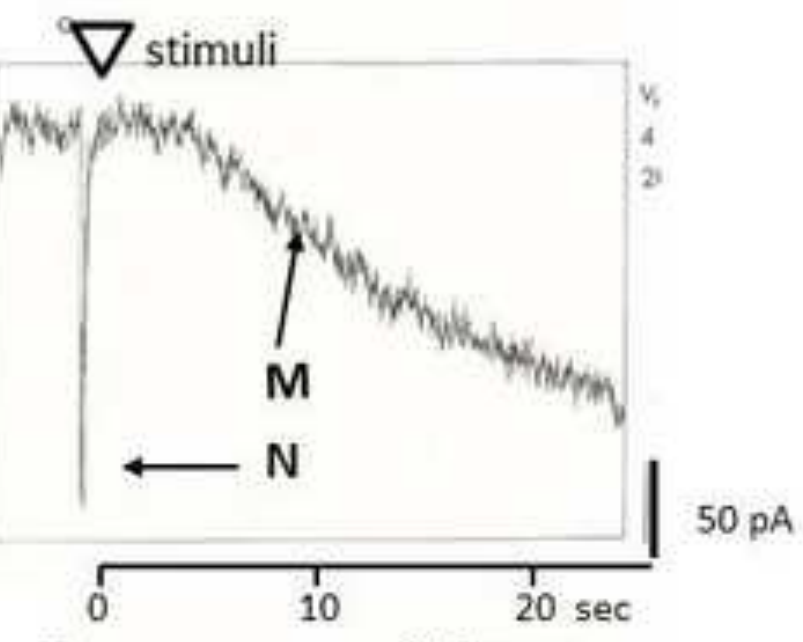
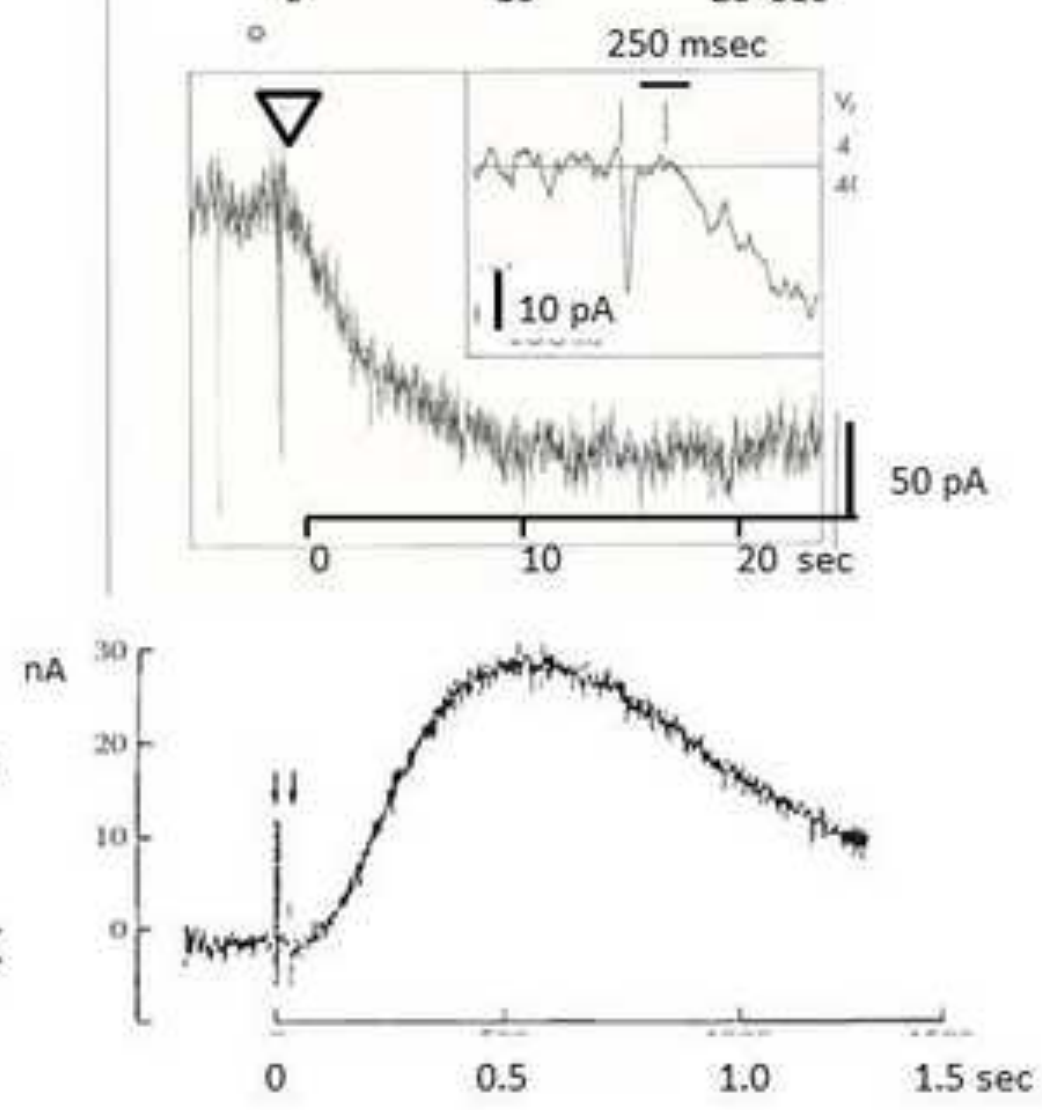
Fig.3

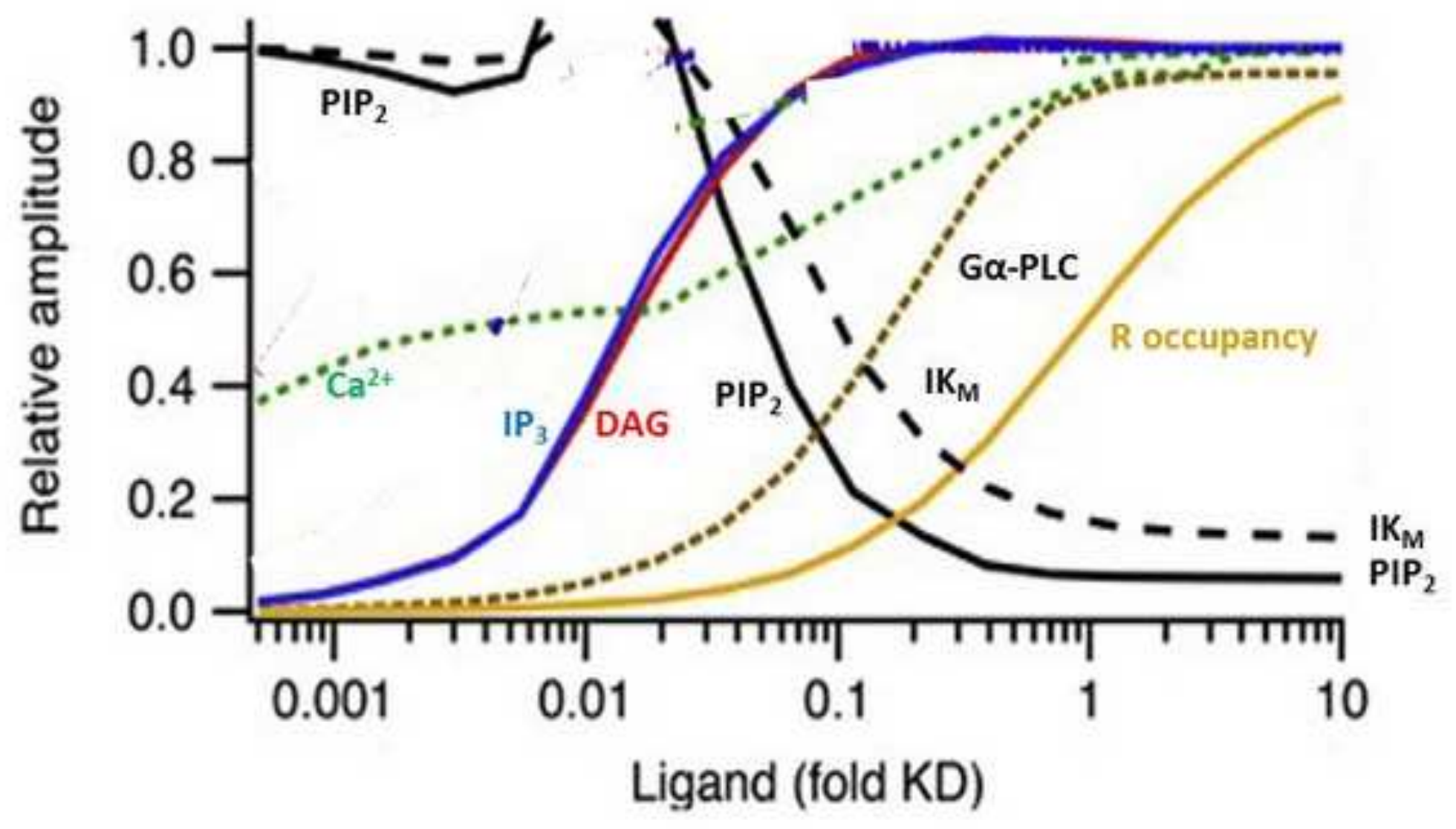

message

apparent KD

$\mathrm{Ca}$

DAG $\quad-\mathrm{PIP}_{2} \quad \mathrm{IK}_{\mathrm{M}}$

agonist $K_{D}$

amplification

$\begin{array}{llll}0.003 & 0.015 & 0.05 & 0.1\end{array}$

1.

$\begin{array}{llll}330 & 67 & 20 & 10\end{array}$

1 


\section{Fig.4}

A

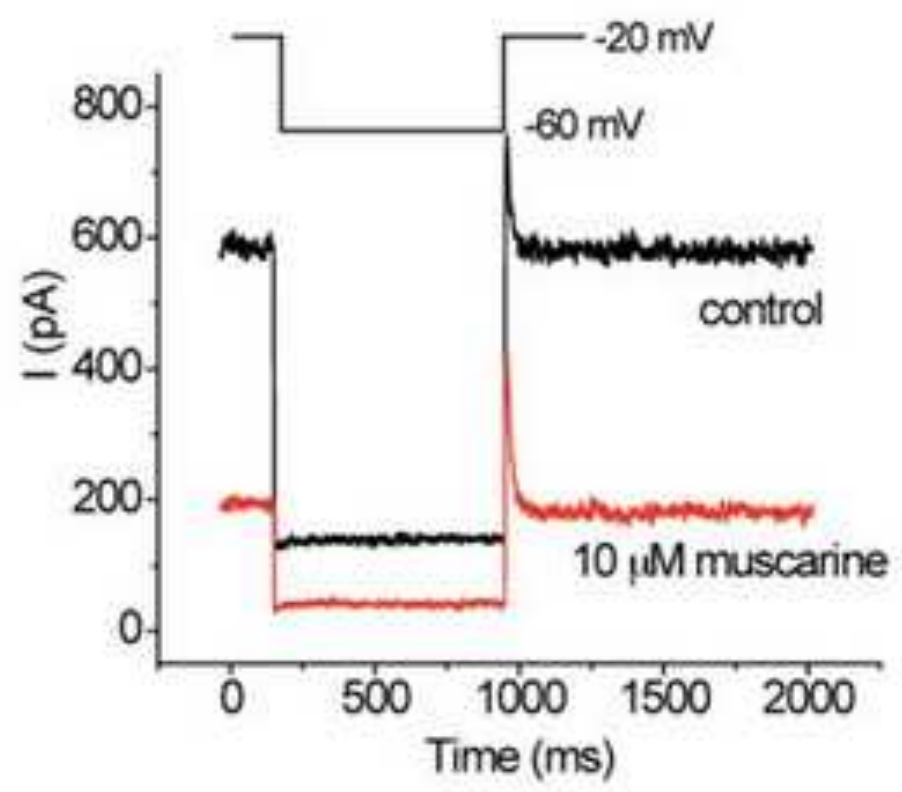

B
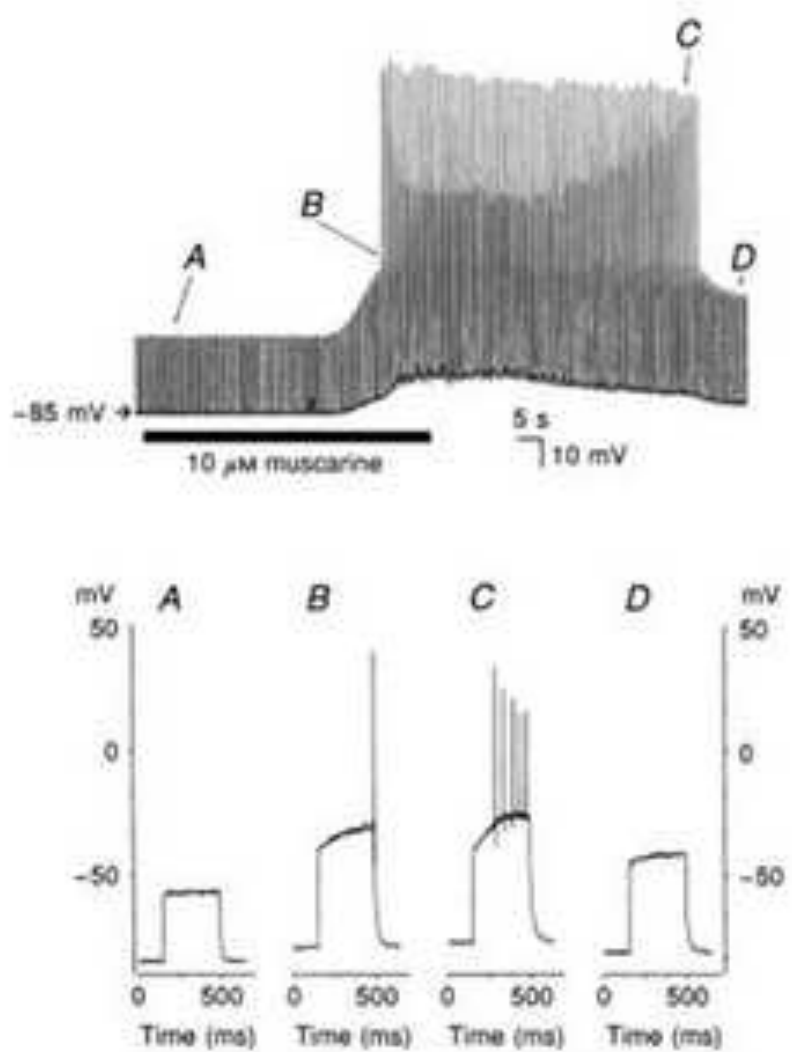
Fig. 5A

\section{Persistent M-current inhibition}

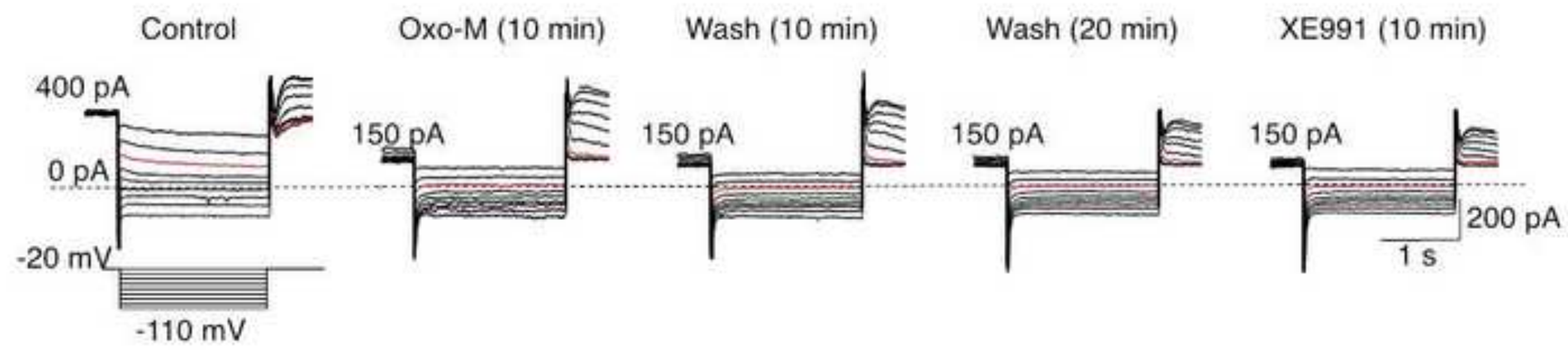

\section{$\mathrm{Ca}_{\mathrm{v}} 3$ channels blocked}

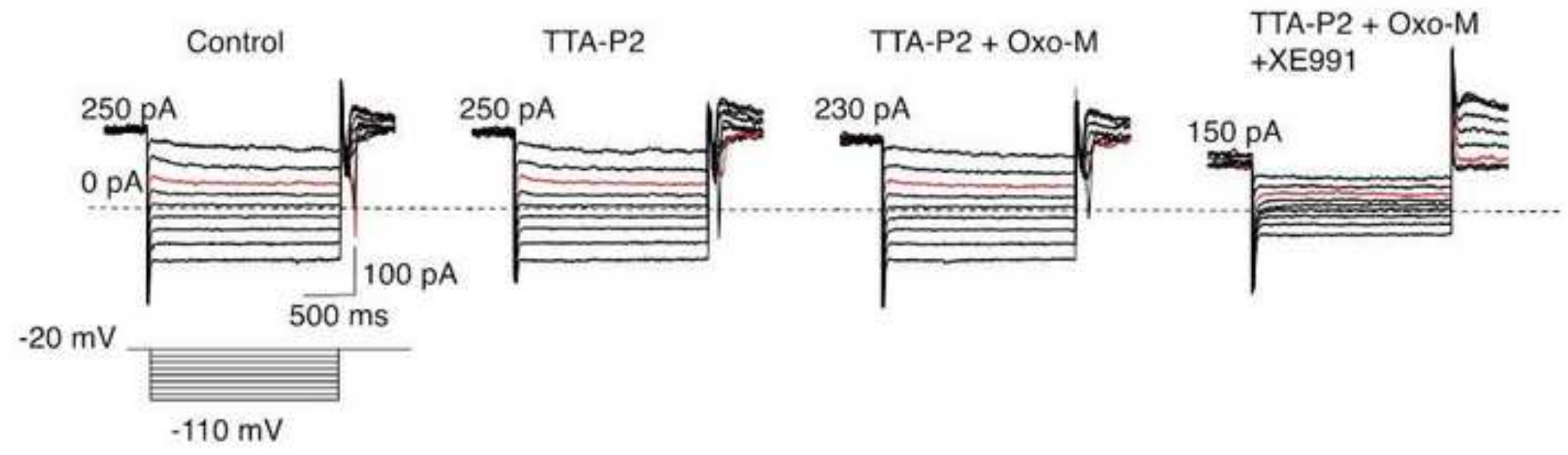


Persistent reduction of AP threshold

control

Oxo-M (1 $\mu \mathrm{M})$

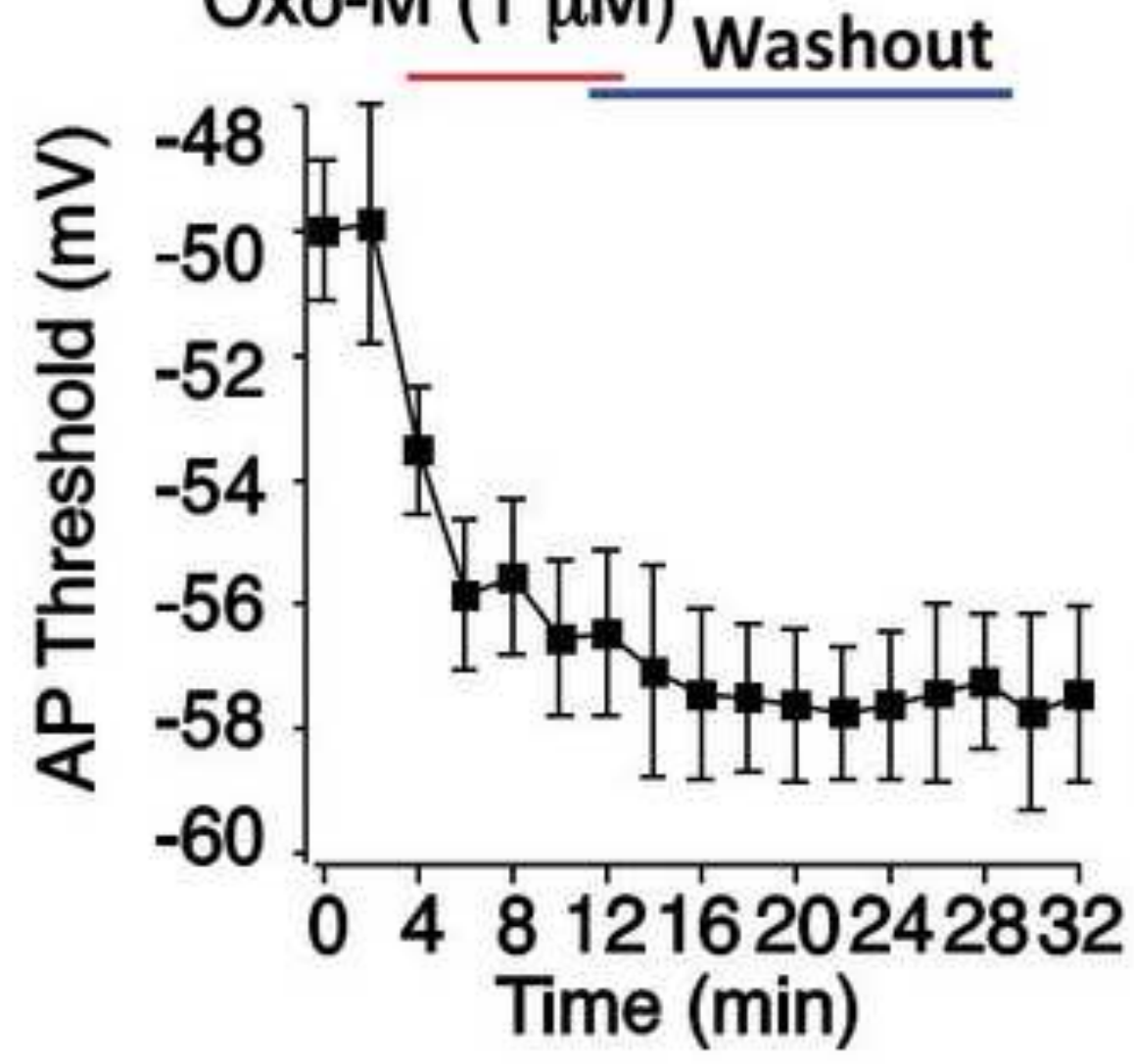

$\mathrm{Ca}_{\mathrm{v}} 3$ channels blocked

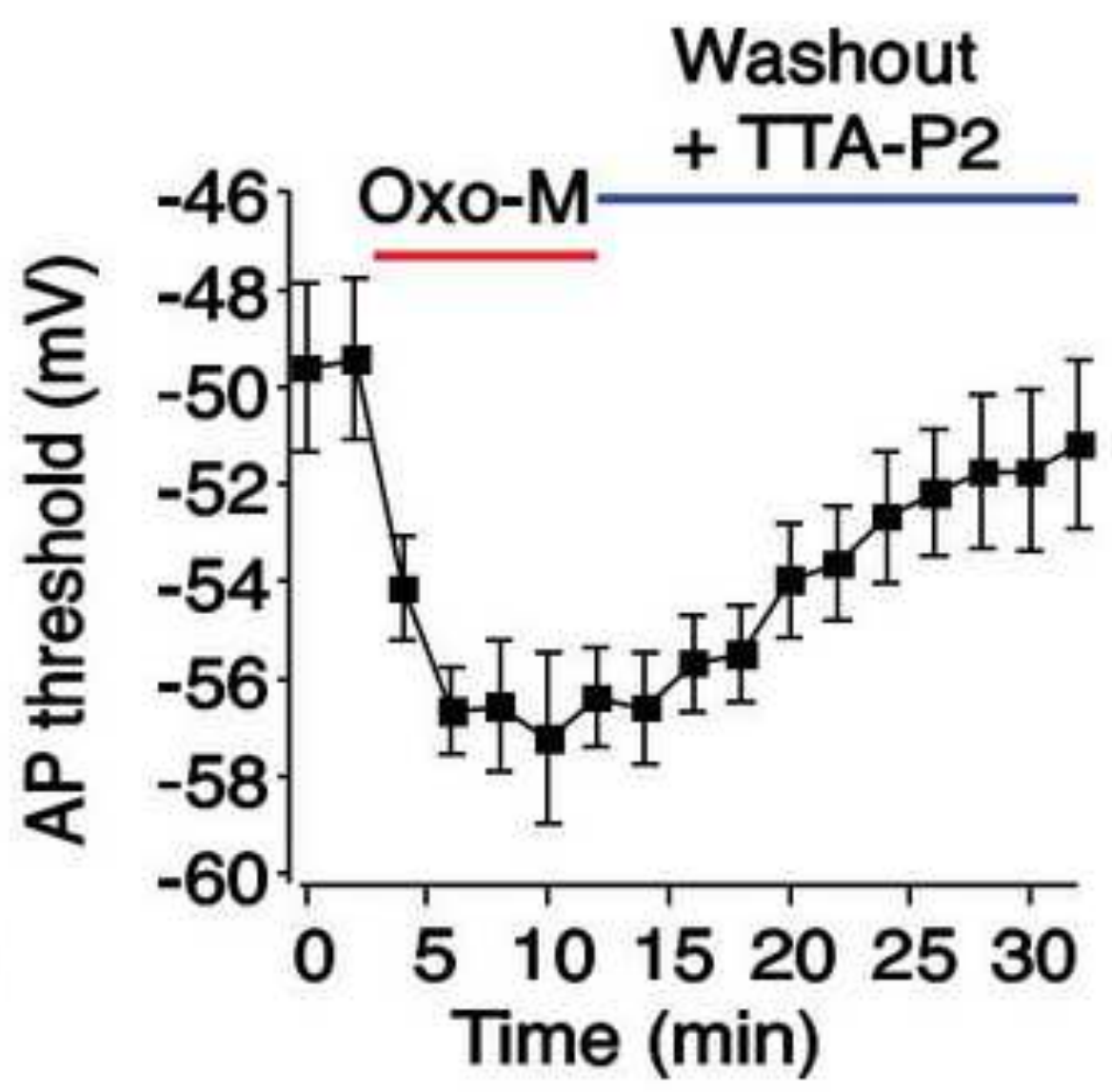


Click here to download high resolution image

\section{Fig.6A}
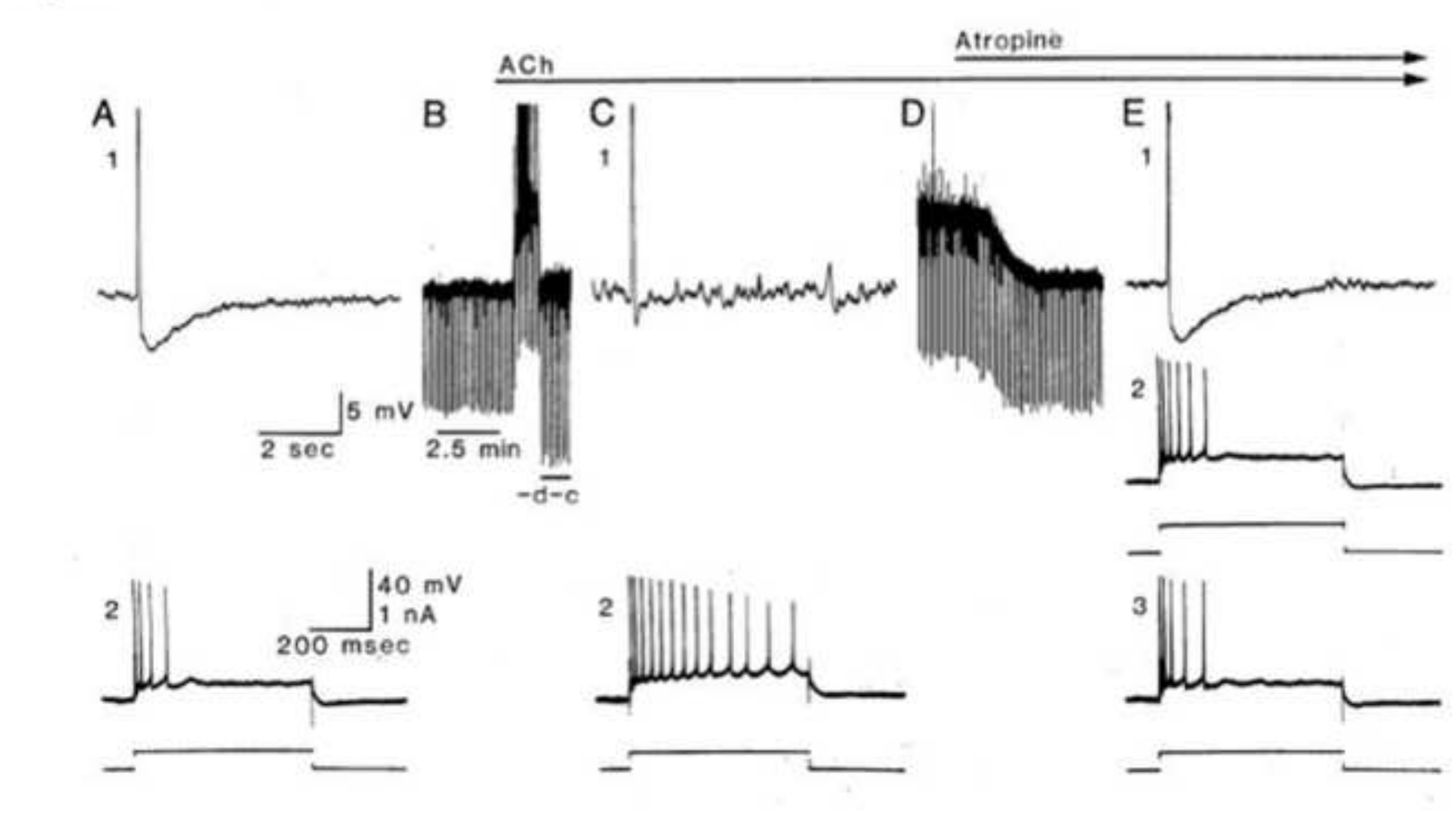

. 


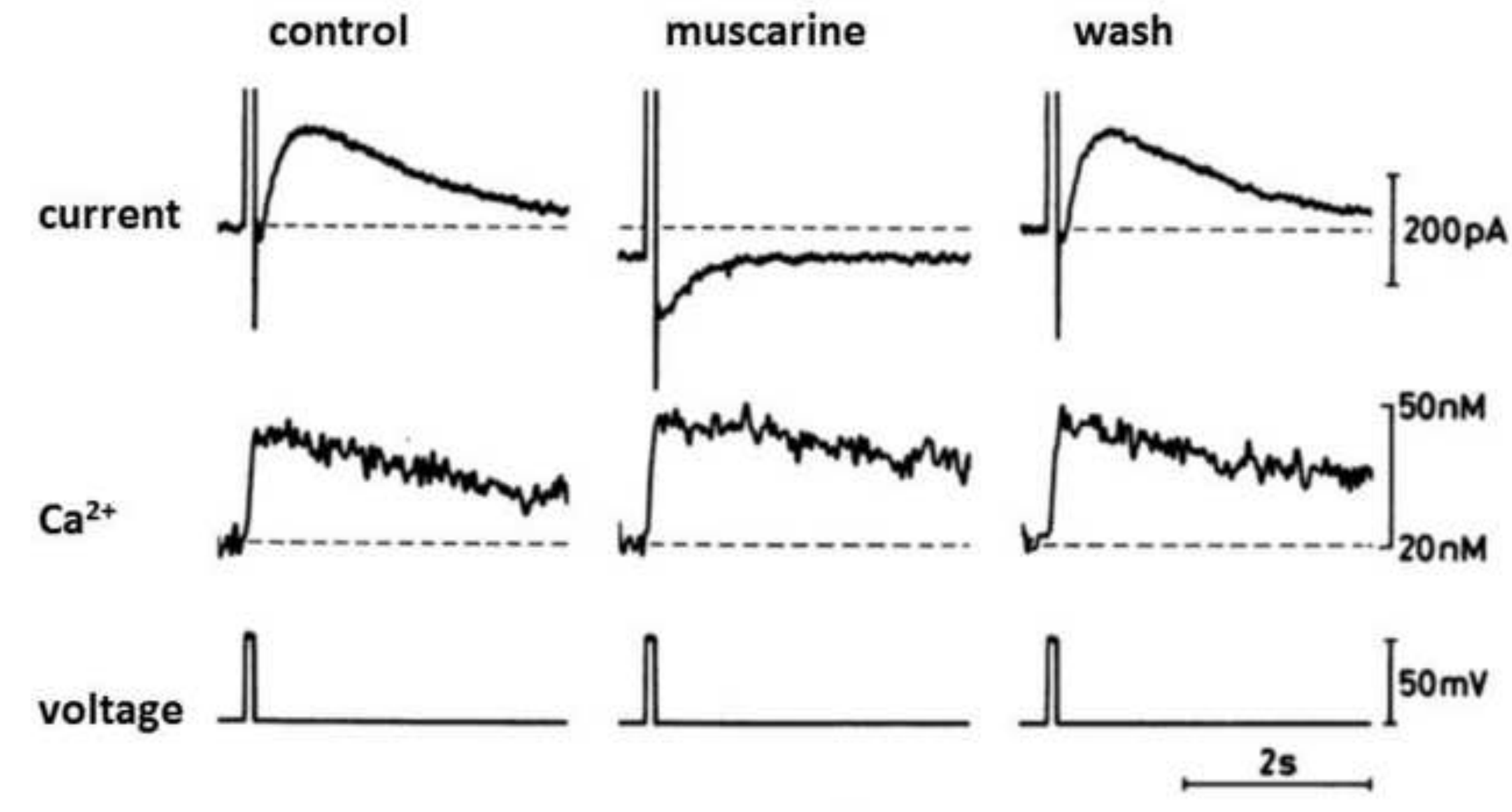

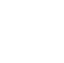

control$$
\text { . }
$$$$
-
$$

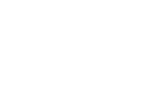

\author{
Fig.6B
}

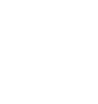

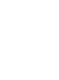

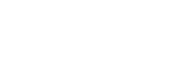
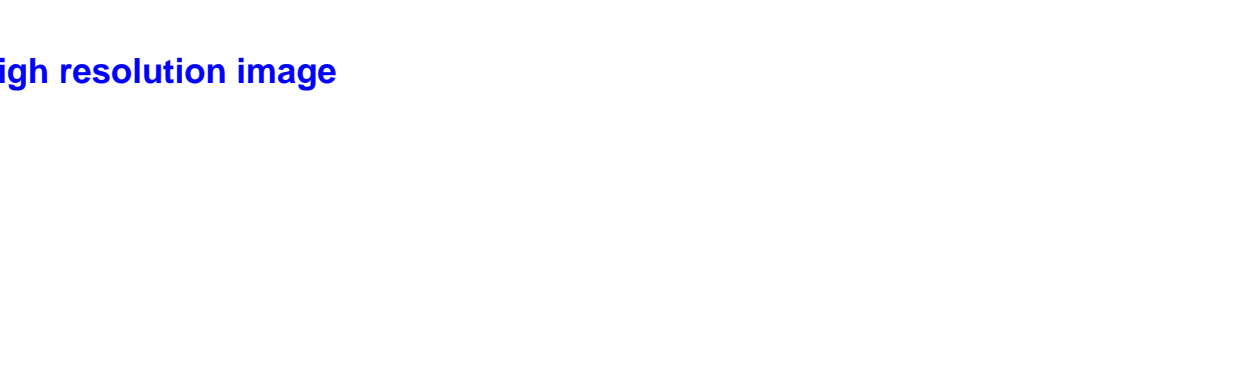

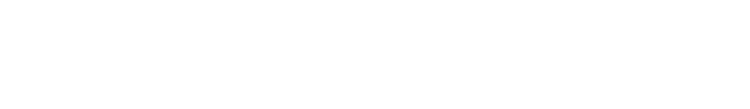

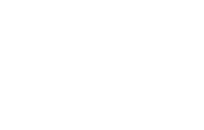

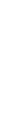

更

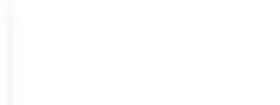

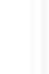

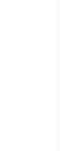

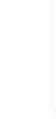

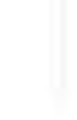

